\title{
A Review on the Fabrication of Electrospun Polymer Electrolyte Membrane for Direct Methanol Fuel Cell
}

\author{
Hazlina Junoh, ,,2 Juhana Jaafar, ${ }^{1,2}$ Muhammad Noorul Anam Mohd Norddin,,2 \\ Ahmad Fauzi Ismail, ${ }^{1,2}$ Mohd Hafiz Dzarfan Othman, ${ }^{1,2}$ Mukhlis A. Rahman,,2 \\ Norhaniza Yusof, ${ }^{1,2}$ Wan Norhayati Wan Salleh, ${ }^{1,2}$ and Hamid Ilbeygi ${ }^{3}$ \\ ${ }^{1}$ Advanced Membrane Technology Research Centre (AMTEC), Universiti Teknologi Malaysia, 81310 Johor Bahru, Johor, Malaysia \\ ${ }^{2}$ Faculty of Petroleum and Renewable Energy Engineering, Universiti Teknologi Malaysia, 81310 Johor Bahru, Johor, Malaysia \\ ${ }^{3}$ Australian Institute for Bioengineering and Nanotechnology (AIBN), The University of Queensland, Building 75, \\ Corner of College and Copper Roads, St Lucia, Brisbane, QLD 4072, Australia
}

Correspondence should be addressed to Juhana Jaafar; juhana@petroleum.utm.my

Received 16 July 2014; Revised 19 August 2014; Accepted 19 August 2014

Academic Editor: Raghu N. Bhattacharya

Copyright (C) 2015 Hazlina Junoh et al. This is an open access article distributed under the Creative Commons Attribution License, which permits unrestricted use, distribution, and reproduction in any medium, provided the original work is properly cited.

Proton exchange membrane (PEM) is an electrolyte which behaves as important indicator for fuel cell's performance. Research and development (R\&D) on fabrication of desirable PEM have burgeoned year by year, especially for direct methanol fuel cell (DMFC). However, most of the R\&Ds only focus on the parent polymer electrolyte rather than polymer inorganic composites. This might be due to the difficulties faced in producing good dispersion of inorganic filler within the polymer matrix, which would consequently reduce the DMFC's performance. Electrospinning is a promising technique to cater for this arising problem owing to its more widespread dispersion of inorganic filler within the polymer matrix, which can reduce the size of the filler up to nanoscale. There has been a huge development on fabricating electrolyte nanocomposite membrane, regardless of the effect of electrospun nanocomposite membrane on the fuel cell's performance. In this present paper, issues regarding the R\&D on electrospun sulfonated poly (ether ether ketone) (SPEEK)/inorganic nanocomposite fiber are addressed.

\section{Introduction}

Currently, the electrospun polymer nanofibers have become important in various applications such as biomedicals [1$3]$, environmental protection $[4,5]$, catalyst and enzyme carriers [6, 7], sensors [3], energy harvest and storage, and many more, due to the property of the one-dimension nanomaterials which have larger surface area and high porosity [8]. A nanofiber can be synthesized via drawing, template, self-assembly, melt blowing, and phase separation [2]. However, these methods are not favorable in industrial practice as producing continuous nanofibers is time consuming compared to the electrospinning method. Within the past few years, the development of a nanocomposite fiber has flourished rapidly and the research and development of the nanocomposite electrospun fiber are starting to grow by adapting the electrospinning method.
Nanocomposite as a layered silicates-polymer is a promising alternative due to the physicochemical, thermal, and mechanical stability of the pure polymer [9]. The manipulation of the advantages offered by layered silicates-polymer nanocomposite membrane has given an insight in developing a new electrolyte for fuel cell system in order to cater for the problem arising via methanol crossover, as well as maintaining or improving the proton conductivity of the fuel cell system, especially on direct methanol fuel cell (DMFC). Compared to the corresponding pure polymer membranes, as well as commercial Nafion membranes, many polymer-inorganic nanocomposite membranes have shown much lower fuel permeability, along with having similar or improved proton conductivity with the nanodispersion of layered silicates throughout the polymer matrix [10]. In general, the smaller the particle sizes of the inorganic fillers are, the larger the conductivity enhancement will be, at 
the same time lowering the methanol permeation. Jaafar et al. [11] conducted an experiment on sulfonated poly (ether ether ketone) (SPEEK) with the addition of Cloisite15A nanofiller having a good compatibility, which showed a slight improvement in the barrier properties of SPEEK. Thus, it has been proven that a good dispersion of Cloisite15A nanofillers with smaller particle size can provide the tortuous path for methanol and eventually decrease the permeability of the methanol.

On the other hand, the research and development on the exact connectivity structure properties within the nanocomposite electrolyte polymer are still in the primary stage and understanding of the ionic conductivity phenomenon in polymer nanocomposite electrolyte is still incomplete. Even so, a large surface area of dispersed nanosized particles within the polymer matrix will decrease the degree of crystallinity of the polymer segments, relative to the ionic mobility in nanocomposite polymer electrolyte membrane system $[12,13]$. Hence, the random dispersion of particles within the polymer matrix can enhance the mobility of ion and eventually perform effectively in the conductivity of fuel cell [14]. Thus, the combination of nanosized particles and specialty polymer electrolyte brings the focus of the study on nanocomposite polymer electrolyte membrane within laboratory, as well as in industrial aspect.

From the morphological point of view, exfoliated polymer-inorganic nanocomposites have been found to be more promising structures than intercalated or ordinary composites, which have a great potential to exhibit high performance nanocomposites [15]. The potential of electrospinning in preparing a homogeneous dispersion of filler within the polymer matrix was studied by Bian [16]. In the study, he found that the dispersion of nanofiller within polymer matrix could be improved by applying electrospinning method compared to the conventional method. The scanning electron microscopy (SEM) images and energy dispersive Xray (EDX-mapping) showed a homogeneous distribution of filler within the polymer matrix, as well as the reduction on agglomerations of the fillers. Therefore, electrospinning process can contribute to the development of exfoliated polymer-inorganic nanocomposite structure and improve the dispersion of Cloisite15A particles in the SPEEK matrices.

\section{Electrolyte Membrane}

In DMFC applications, an electrolyte membrane is called a "proton exchange membrane," which refers to the acid electrolyte and certain polymers that contain free $\mathrm{H}^{+}$ions. In other words, this proton exchange membrane only can serve for transferring $\mathrm{H}^{+}$within the electrolyte membrane from anode to cathode or vice versa effectively [17]. A good proton exchange membrane should have good intrinsic properties, which will enable them to work effectively in fuel cell applications $[18,19]$. These intrinsic properties include the following:

(1) high proton conductivity to support high currents with minimal resistive losses and zero electronic conductivity;

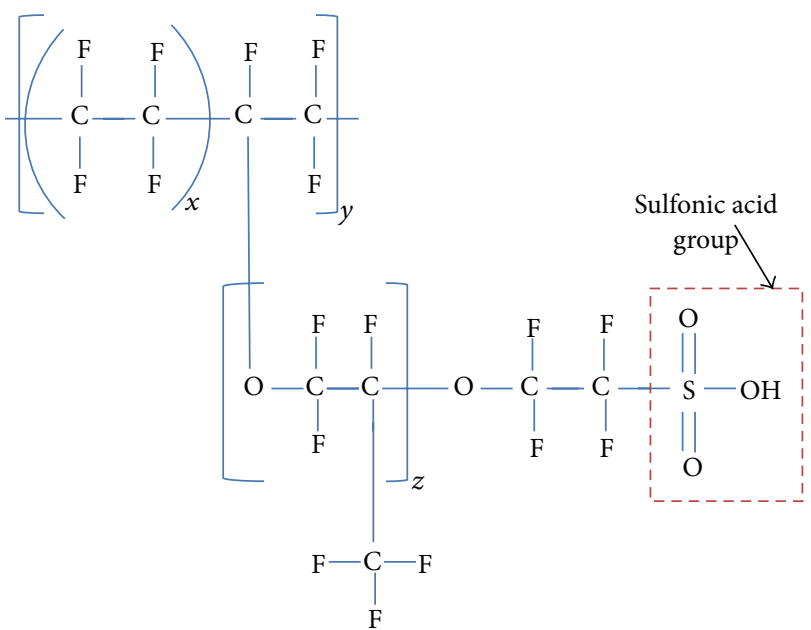

FigURE 1: Structure of Nafion with sulfonic acid group $(x=5-13.5$, $y=1000, z \geq 1$ ).

(2) tolerable mechanical strength and stability;

(3) chemical and electrochemical stability under operation conditions;

(4) extremely low fuel or oxidant bypass to maximize columbic efficiency;

(5) low water transport through diffusion;

(6) electroosmosis and capability for fabrication into membrane electrode assemblies.

Conventionally, Nafion serves as an electrolyte in hydrogen-oxygen fuel cell applications, which are mostly used in proton exchange membrane fuel cell (PEMFC) and DMFC, due to the presence of higher conductivity and thermal stability of the Nafion [20]. The presence of sulfonic acid groups at the side chain of the Nafion makes it possible for proton conductivity [21] (Figure 1). Water present in the hydrophilic regions solvates the protons of the sulfuric acid groups and allows the protons to "hop" through the channels [21]. In case of DMFC, the protons will hop from anode to cathode.

However, Nafion faces several challenges which limit its industrial applications. One of the drawbacks is the high production cost, as well as low conductivity at high temperatures, due to fast dehydration and loss of fluorine ion affected by $\mathrm{OH}$ radical attack [22]. The most apparent drawback of the Nafion membrane in DMFC applications is methanol crossover and decrease in conductivity at temperature higher than $100^{\circ} \mathrm{C}$ [20]. Li et al. [23] found that the replacement of Nafion 115 membrane with SPEEK gave a significant increase in performance on DMFC application since methanol permeation is generally much lower compared to Nafion 115 . However, the proton conductivity was found to remain barely unchanged at the operating temperature of $80^{\circ} \mathrm{C}$.

The proton exchange membrane (PEM) primarily consists of many proton-conductive functional groups, which only allow a proton to transfer from one group to another [18]. The proton conductivity of the ionomer membrane 
TABLE 1: Overview on electrolyte composite membrane for fuel cell application.

\begin{tabular}{|c|c|c|c|c|c|c|}
\hline $\begin{array}{l}\text { Matrix } \\
\text { Polymer }\end{array}$ & Fillers & Proton conductivity & $\begin{array}{l}\text { Methanol } \\
\text { permeability }\end{array}$ & $\begin{array}{c}\text { Filler's } \\
\text { distribution }\end{array}$ & $\begin{array}{l}\text { Type of fuel } \\
\text { cell }\end{array}$ & Ref. \\
\hline SPEEK & Cloisite 15A/TAP & Lower than Nafion 112 & $\begin{array}{l}\text { Significantly } \\
\text { reduced }\end{array}$ & $\begin{array}{c}\text { Partially } \\
\text { exfoliated }\end{array}$ & DMFC & {$[11]$} \\
\hline SPEEK & $\begin{array}{l}\text { MMT/silicotungstic } \\
\text { acid }\end{array}$ & $\begin{array}{l}\text { Slight enhancement of proton } \\
\text { conductivity }\end{array}$ & Suppressed & - & DMFC & {$[22]$} \\
\hline $\mathrm{PVOH}$ & $\begin{array}{l}\text { Cloisite } \\
\mathrm{Na}^{+} / \text {phosphotungstic } \\
\text { acid }\end{array}$ & $\begin{array}{l}\text { Slight decrease of ionic } \\
\text { conductivity }\end{array}$ & $\begin{array}{l}\sim 88 \% \text { reduced with } \\
\text { respect to neat } \\
\text { polymer }\end{array}$ & Exfoliated & DMFC & {$[24]$} \\
\hline SPEEK & $\begin{array}{l}\text { Silica sulfuric acid } \\
\text { (SSA) }\end{array}$ & $\begin{array}{l}18.6 \% \text { higher than pristine } \\
\text { SPEEK } \\
8.6 \% \text { higher than Nafion } 117\end{array}$ & - & - & PEMFC & {$[80]$} \\
\hline SPEEK & $\begin{array}{l}\text { Heteropolyacids } \\
\text { (HPA) }\end{array}$ & Higher than Nafion & - & - & PEMFC & {$[81]$} \\
\hline Nafion & $\begin{array}{l}\text { Organoclay, } \\
\text { montmorillonite } \\
\text { (Cloisitel 10A) } \\
\end{array}$ & Remains similar to Nafion 117 & $\begin{array}{l}\text { Slightly decreases } \\
\text { compared to the } \\
\text { Nafion } 117\end{array}$ & Exfoliated & DMFC & {$[82]$} \\
\hline Nafion & $\begin{array}{l}\text { Montmorillonite } \\
\text { (MMT) }\end{array}$ & $\begin{array}{l}\text { Comparable with unmodified } \\
\text { Nafion }\end{array}$ & $\begin{array}{l}\text { Significantly } \\
\text { decreases } \\
\text { compared to } \\
\text { unmodified Nafion }\end{array}$ & Exfoliated & DMFC & {$[83]$} \\
\hline Nafion & Laponite & $\begin{array}{l}\text { Higher than commercial Nafion } \\
\text { membrane }\end{array}$ & - & - & PEMFC & {$[84]$} \\
\hline
\end{tabular}

depends on the presence of water, but due to the high evaporation rate at temperature above $100^{\circ} \mathrm{C}$, the membrane undergoes a drastic dehydration and will eventually have its conductivity potential reduced. In order to cater for these behaviors of the membrane especially at high temperature, some approaches have been pursued [20]. New approaches such as modified perfluorinated ionomer membrane, acidbase blends, and new electrolyte composite membrane based on proton conducting materials [20] have been shown as promising solution regarding proton conductivity and methanol barrier properties. The new electrolyte composite membranes consist of polymer and other inorganic fillers such as silica, zirconium phosphate, and heteropolyacid. However, the methanol barrier properties are still lacking due to the size and shape of the fillers [24]. Dispersion degrees of inorganic fillers within the polymer matrix are important since they will determine whether the nanocomposite will form either as an intercalated, exfoliated or flocculated nanocomposite membrane [25]. Some of the modified parent matrix polymers for fuel cell application are summarized in Table 1.

Other than that, a novel application of SPEEK/Cloisite15A on microbial fuel cell (MFC) system has been pursued by Yusof et al. [26]. In their research, they found that the use of SPEEK incorporated with Cloisite15A could enhance the performance of MFC system in terms of water uptake, dissolved oxygen permeability, and morphology, which became more uniform with a lot of small pores, and the surface was smoother compared to the SPEEK membrane. However, the mechanical strength of the composite membrane was not improved, due to the higher degree of sulfonation (76\% DS) which lowered the mechanical strength. The higher degree of sulfonation signifies a high content of $\mathrm{SO}_{3}{ }^{-}$ion, which functions to absorb more protons as well as water in the system, whereas a lower degree of sulfonation (41-60\%) could absorb much lesser protons compared to the Nafion membrane [27] which needs to be avoided. Thus, a moderate degree of sulfonation is crucial in order to maintain the mechanical strength of the electrolyte membrane.

Other than Cloisite15A, the incorporation of sulfonated silica nanoparticles within sulfonated polymers membrane can also improve the thermal stability and methanol barrier properties. Su et al. [28] studied the effect of sulfonated silica nanoparticles on the proton conductivity instead of methanol permeability in sulfonated poly (phthalazinone ether ketone) polymer matrix for DMFC. In their study, they found that the interaction between the sulfonated silica nanoparticles and the sulfonated polymer could enhance a continuous proton conductive pathway for better proton conductivity. Furthermore, Gosalawit et al. [29] in their study had found that the increase of sulfonated montmorillonite (S-MMT) loading content within the SPEEK membrane reduced the methanol permeability, whereas the proton conductivity was increased compared to the pristine SPEEK and Nafion 117 membranes for DMFC applications. From the latter study, it can be suggested that the introduction of sulfonated nanoparticles will significantly enhance proton conductivity but not methanol permeability. However, the improvement in proton conductivity has significantly suppressed the methanol permeability problem. Since methanol permeability is a major 
concern in DMFC application, the study on the alternative approach in producing a desirable electrolyte membrane has been chosen as the main focus of this study.

\section{Technique for Nanofiber Formation}

Electrospinning is one of the techniques involved in nanofiber formation, which accommodates manipulation of polymers. High voltage electrostatic field is used to charge the surface of the polymer solution droplet and, thus will, induce the ejection of a liquid jet through the needle tip. At this rate, the electrostatic force overcomes the surface tension of the droplet and the formation of the Taylor cone is obtained when the solution exits the tip of the needle, which eventually leads to charged jet (Figure 2(a)) [30-33]. The formation of Taylor cone is proportional to the applied voltage, where the voltage keeps increasing until the equilibrium condition is achieved between the surface tension and the electrostatic force (Figure 2(c)). The electric field controls the route of charged jet and the solidified spun fiber will be collected by the rotating or stationary conductive collector [21,31-34].

Compared with the conventional methods such as wet spinning, dry spinning, and melt spinning, the electrospinning method can produce a much larger specific surface area and smaller pores size having fiber diameter in the range of $10 \sim 1000 \mathrm{~nm}$ by adjusting the operating parameters of the electrospinning, whereas the conventional methods can only produce fibers with diameter in the range of $5 \times 10^{3} \sim$ $500 \times 10^{3} \mathrm{~nm}$ [35]. Electrospinning can produce membranes with small diameter in the range of $10 \sim 1000 \mathrm{~nm}$ with high porosity due to random deposition on the collector [36]. Other than producing nanofiber, electrospinning has other advantages such as low cost, more capability, and high speed, which makes it highly potential in producing nanocomposite fiber [37]. The unique properties such as extremely long, large surface area, complex pore size, and complex alignment on either woven or nonwoven fiber possessed by electrospun nanofibers make it practical in various applications $[8,30,38]$ especially in fuel cell system. Other than electrospinning process, drawing, template synthesis, phase separation, and self-assembly are other common methods for developing nanofibers [2]. However, due to the versatility possessed by electrospinning process, it is more favorable to be used in developing highly porous, patterned, and nanofibrous polymeric materials of nanofibers [39].

(i) Drawing Process. Drawing process can produce one to one long continuous single nanofiber as the dry spinning process in preparing hollow fiber membranes. However, only a viscoelastic material is used in this process, which can hold together firmly when the pulling process takes place in order to produce a nanofiber [2]. Bajáková et al. [40] in their study had successfully produced individual nanofibers consisting of polyvinyl alcohol (PVA), poly ( $\varepsilon$-caprolactone) (PCL), poly (vinyl butyral) (PVB), polyethylene oxide (PEO), and poly methyl methacrylate (PMMA) by pulling from the polymer droplets using a micropipette, respectively. The finest fibers

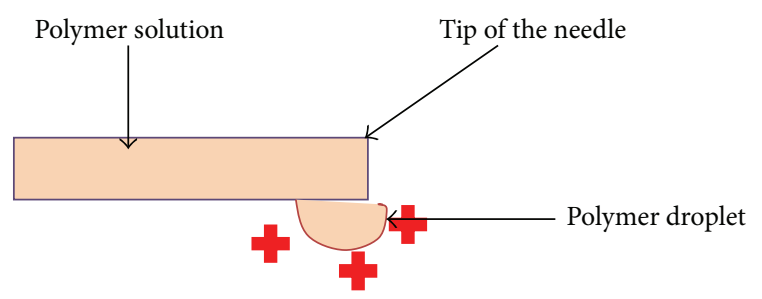

(a)

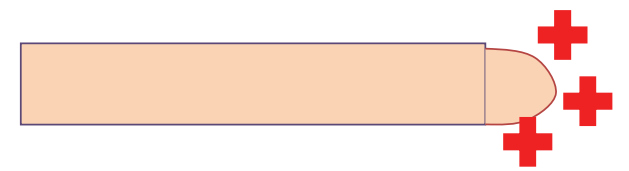

(b)

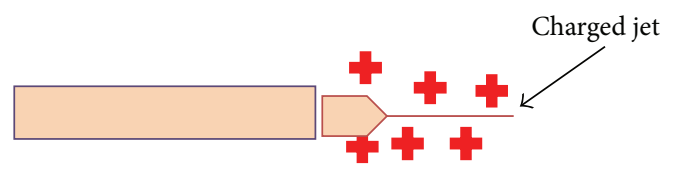

(c)

FIgURE 2: Formation of Taylor cone upon the equilibrium of electrostatic field, in which surface tension is achieved as the voltage is increased (Figure 2(c)).

from PVA with diameter of $200 \mathrm{~nm}$ were successfully produced.

(ii) Template Synthesis. Template synthesis is used to make nanofibers of solid or hollow shape. The most important aspect of this method may depend on the raw material used for fabricating the nanofibers. Unfortunately, a template synthesis can only produce discontinuous nanofibers that are unusually required in developing nanofibers in a big scale [2]. Martin [41] and his colleague had explored a template synthesis method in order to synthesize the desired material within the pores of a nanoporous membrane, in which he and his colleague had prepared tubules and fibrils composed of electronically conductive polymers, metals, semiconductors, carbons, and other materials.

(iii) Phase Separation. Phase separation consists of dissolution, gelatin, and lineage (extraction) which eventually gives a nanoscale porous foam formation. This phase separation process takes relatively a longer time to produce nanoporous foam from a solid polymer [2].

(iv) Self-Assembly. Self-assembly process is a process which involves an individual component, where preexisting components organize themselves into desired patterns and functions. However, this process also is a time consuming process in developing continuous polymer nanofibers [2].

Among the aforementioned preparation methods for polymer nanofibers, it can be concluded that the electrospinning method is the most versatile processing method compared to drawing, template synthesis, phase separation, and self-assembly methods, owing to the simple and easy production of polymer nanofibers. The electrospinning 
TABLE 2: Parameters that influence the formation of fiber morphology and structure.

\begin{tabular}{lcccc}
\hline \multicolumn{1}{c}{ Solution parameters } & & Process parameters & Ambient parameter \\
Parameter (unit) & Range & Parameter (unit) & H-100 & Humidity \\
\hline Concentration (wt.\%) & $1-40$ & Voltage $(\mathrm{kV})$ & $0.2-10$ & Pressure \\
Viscosity $(\mathrm{cP})$ & $20-300000$ & Electric field strength $(\mathrm{kV} / \mathrm{cm})$ & $1-100$ & Temperature \\
Surface tension $(\mathrm{mN} / \mathrm{m})$ & $20-75$ & Needle to collector distance $(\mathrm{cm})$ & $0.01-5$ & $0.1-3$ \\
Dielectric constant & $15-90$ & Feed rate $(\mathrm{ml} / \mathrm{h})$ & Orifice diameter $(\mathrm{mm})$ & \\
\hline
\end{tabular}

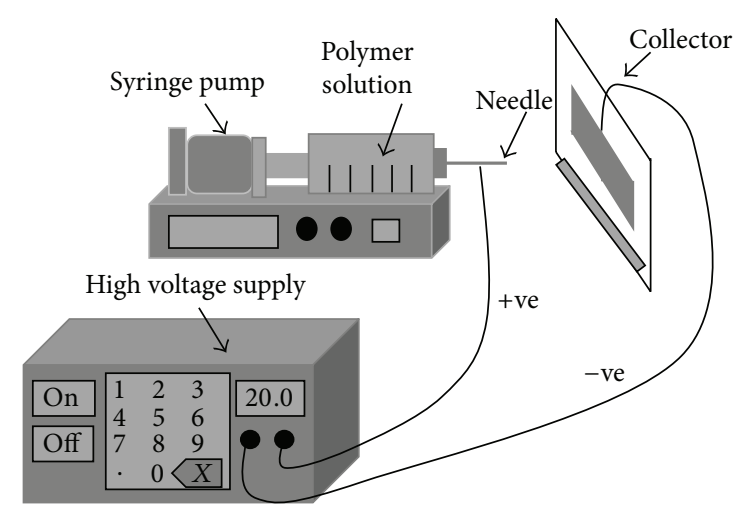

FIGURE 3: Basic setup of electrospinning consisting of needle connected to the infusion pump (constant flow rate for solution at the needle tip), high power supply $(\mathrm{kV})$, and collector (either moving or stationary).

process can be advanced for mass production of long continuous nanofibers from various types of polymers, as well as metals and ceramics [42]. Furthermore, the electrospinning method can offer electrospun nanofibers with higher network ion exchange capability, which is crucial for proton transport process in fuel cell system, especially in DMFC.

\section{Electrospinning Process and Setup}

Electrospinning is a simple and versatile method for generating an ultrafine fiber from rich variety materials which include polymer, composite, and ceramic. The electrospinning setup consists of three major components which are high voltage power supply, syringe with metal needle, and a conductive collector. The parameters that influence the morphology and structure of the produced electrospun fiber are listed in Table 2. However, these parameters generally depend upon the environmental condition in the respective state or country.

Electrospinning seems to be a very sophisticated but in fact a simple processing method of producing nanofiber. According to Liu et al. [43] the electrospinning process can be divided into several techniques such as vibration electrospinning, magneto-electrospinning, siro-electrospinning, and bubble electrospinning. Figure 3 shows the basic setup for electrospinning. As the charge liquid jet travels from the syringe tip to the collector, the mode of current flow changes from ohmic to convective flow as the charge migrates to

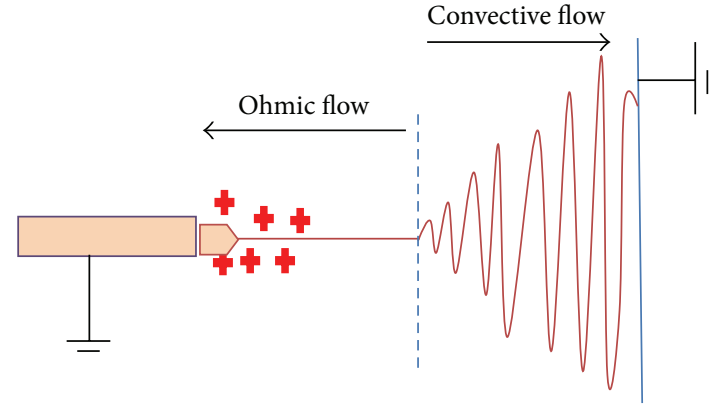

Figure 4: Mode of current flow for jet to travel from tip of the needle to collector.

the surface of the fiber (Figure 4). The ohmic flow is governed by a slow acceleration since the geometry of the Taylor cone [44] is controlled by the ratio of the surface tension to electrostatic repulsion. After overcoming the ohmic flow, the jet will travel at a rapid acceleration, which includes the zone of transition from liquid to dry solid. Eventually, the jet will penetrate the collector [21, 31-34, 45-48].

4.1. Operating Parameters for Electrospinning. As stated earlier, the electrospinning process is affected by three main parameters, which are solution parameters, process parameters, and ambient parameters. These operating parameters play a big role in determining the desired quality of the electrospun fiber produced $[33,49]$. A fiber with diameter within 10 1000 $\mathrm{nm}$ in scale and a smooth surface morphology is the most preferred in many applications. According to Baji et al. [44], the solution properties are difficult to alter since the relation between one parameter will drag the other parameters and they are very difficult to isolate as one controllable parameter. Table 3 shows all three major parameters which can affect the morphology and diameter of the electrospun fiber.

Li and Wang [50] discussed the effects of working parameters that govern the electrospinning process, in which they found that these parameters could affect the fiber morphologies and diameters. Thompson et al. [51], in their study on the effects of the parameters on nanofiber diameter, found that the jet radius could affect the production of the electrospun fiber. In their study, parameters such as distance of needle to the collector, solution viscosity, diameter of the needle, charge density, and relaxation time greatly affected the fiber formation compared to other parameters. For instance, 
TABLE 3: Parameters affecting morphology and diameter of the electrospun nanofiber [33].

\begin{tabular}{ll}
\hline Categories & Processing parameters \\
\hline Solution properties & $\begin{array}{l}\text { Type, confirmation, dipole moment, dielectric constant, crystallinity, glass transition temperature, molecular } \\
\text { weight, molecular weight distribution of polymer, vapor pressure, polarity, surface tension of the solvent, } \\
\text { viscosity/concentration, elasticity, and electrical conductivity of solution }\end{array}$ \\
\hline Controlled variables & $\begin{array}{l}\text { Solution feeding rate, electric field strength, distance between the tip of the needle and the collector, needle } \\
\text { diameter, shape and length, composition, geometry, and motion of the collector }\end{array}$ \\
\hline Ambient parameter & Temperature, humidity, and air velocity \\
\hline
\end{tabular}

TABLE 4: Electrospinning parameters and their effects on fiber morphology and fiber diameter.

\begin{tabular}{|c|c|c|}
\hline Parameter & Remarks & Reference \\
\hline Applied voltage & $\begin{array}{l}\text { Deposition pattern of fibers changes from random orientation into a straight arrangement. } \\
\text { Fiber bead density increases with increasing instability due to the increase of the applied voltage. } \\
\text { Increasing applied voltage, thinning the fiber, reducing average diameter of the fiber, and causing } \\
\text { multiple jets. } \\
\text { Higher applied voltage broadens the distributions of the diameters of fiber. }\end{array}$ & [85-88] \\
\hline $\begin{array}{l}\text { Distance between } \\
\text { tip and the collector }\end{array}$ & $\begin{array}{l}\text { Jet diameter decreases with increasing distance. } \\
\text { At short distance, the fibers are not completely stabilized and eventually the cross-sections of spun } \\
\text { fiber become flatter and some fibers stick together becoming bundle fiber. } \\
\text { At long distance, the fibers exhibit a straight; cylindrical morphology indicates the fiber mostly } \\
\text { dried when reaching the collector. }\end{array}$ & {$[85,87]$} \\
\hline Concentration & $\begin{array}{l}\text { Below critical concentration, the fiber jet will break down due to generation of mixture of fibers } \\
\text { and droplets jet. } \\
\text { Above the critical concentration, a stable jet is difficult to form. } \\
\text { Bimodal distribution of fiber diameters is possible to form from higher concentration solutions. } \\
\text { Decreasing concentration will reduce the diameter of electrospun fiber; further decrease will form } \\
\text { beaded fibers. }\end{array}$ & {$[85,86,88]$} \\
\hline Viscosity & $\begin{array}{l}\text { Too diluted solution is difficult to form a stable jet; the jet will break whereas too viscous solution } \\
\text { will make it difficult to form fiber due to the solution drying at the tip. } \\
\text { Higher viscosity produces fiber without beads. }\end{array}$ & {$[85,89]$} \\
\hline $\begin{array}{l}\text { Surface tension of } \\
\text { solution }\end{array}$ & $\begin{array}{l}\text { Reduced surface tension will produce fibers without beads. } \\
\text { Reduced surface tension will form a larger diameter of the fibers. } \\
\text { (Depending on polymer and solvent.) }\end{array}$ & {$[89]$} \\
\hline Net charge density & Adding $\mathrm{NaCI}$ or salts will increase the net charge density and reduce diameter of the fiber. & {$[88,89]$} \\
\hline Feeding rate & $\begin{array}{l}\text { At higher feeding rate, this will exceed the delivery rate of solution with applied voltage and } \\
\text { eventually result in tiny drops of jet on the collector. } \\
\text { At low feeding rate, the solution is ejected faster and the shift of the mass balance will result in } \\
\text { sustained but unstable jet which eventually forms fiber with beads. }\end{array}$ & {$[87]$} \\
\hline Molecular weight & $\begin{array}{l}\text { Molecular weight affects the manipulated concentration in order to electrospin fine fibers. } \\
\text { Low molecular weight can easily form nonuniform fibers with bead. } \\
\text { High molecular weight will be able to produce uniform fibers without bead. }\end{array}$ & {$[88]$} \\
\hline
\end{tabular}

the first electrospinning method by Formhals faced some technical disadvantages since it was difficult to completely dry the fibers after electrospinning due to the short distance between the spinning and collection zones, which resulted in a less aggregated web structure [52]. However, after 5 years, Formhals [53] had polished his first work by altering the distance between the nozzle and the collecting device to give more drying time for the electrospun fibers [54] with longer distance.

As concerned, a support material is crucial for fuel cell system, especially on electrospun fiber, in order to maintain its mechanical strength in concurrence with increasing the performance of the fuel cell system. For instance, Choi et al. [55] conducted an experiment on an electrospun PVDF membrane, impregnated with various amounts of Nafion $(0.3-0.5 \mathrm{~g})$, and found that $0.4 \mathrm{~g}$ of Nafion is the optimum amount that exhibited higher proton conductivity and lower methanol permeability in DMFC application, compared to unmodified Nafion 115 which had lesser thickness with area of $5 \mathrm{~cm} \times 5 \mathrm{~cm}$. Table 4 shows a review on electrospinning parameters and their effects toward fiber morphology and fiber diameter.

For instance, Pelipenko et al. [54] claimed that the humidity was found to be the most important parameter 
TABLE 5: Desired properties for some desired applications of electrospun nanofiber.

\begin{tabular}{|c|c|c|c|}
\hline Application & Tissue engineering & Filter media & Fuel cell \\
\hline Material & $\begin{array}{l}\text { Poly (D,L-lactide-co-glycolide) } \\
\text { (PLGA) }\end{array}$ & Polyacrylonitrile (PAN) & $\begin{array}{l}\text { Sulfonated poly (arylene ether } \\
\text { sulfone) (sPAES) }\end{array}$ \\
\hline Morphology & $\begin{array}{l}\text { Nonwoven, } \\
\text { highly porous }\end{array}$ & $\begin{array}{l}\text { Solution with low mass fraction } \\
\text { produces beads on fiber and high } \\
\text { mass fraction produces smooth and } \\
\text { uniform fiber }\end{array}$ & $\begin{array}{l}\text { Clear nanofiber with uniform dense } \\
\text { Norland Optical Adhesive (NOA) } \\
63 \text { polymer filled completely the } \\
\text { interfiber void of nanofiber }\end{array}$ \\
\hline $\begin{array}{l}\text { Average diameter } \\
(\mathrm{nm})\end{array}$ & $500-800$ & $270-400$ & $\begin{array}{l}40-160 \text { (at first stage) } \\
\text { can increase to } 0.73-165 \text { (after } \\
\text { compaction/embedded) }\end{array}$ \\
\hline $\begin{array}{l}\text { Mechanical } \\
\text { strength }\end{array}$ & $\begin{array}{l}\text { Higher along with decrease in } \\
\text { diameter of fiber }\end{array}$ & NA & Increased for embedded nanofibers \\
\hline $\begin{array}{l}\text { Controlled } \\
\text { parameter }\end{array}$ & $\begin{array}{l}\text { Voltage of } 18 \mathrm{kV}, 20 \mathrm{~mL} \text { glass } \\
\text { syringe, } 18 \mathrm{G} \text { needle, } 20 \mathrm{~cm} \text { needle } \\
\text { to collector distance, copper } \\
\text { collecting plate }\end{array}$ & $\begin{array}{l}5 \mathrm{~cm} \text { needle to collector distance, } \\
\text { humidity controlled chamber in } \\
\text { pure } \mathrm{N}_{2}, 25 \% \text { relative humidity, } \\
\text { voltage of } 3-10 \mathrm{kV}, 400 \mu \mathrm{m} \text { inner } \\
\text { diameter capillary }\end{array}$ & $\begin{array}{l}\text { NA } \\
\text { rotating drum (horizontally) }\end{array}$ \\
\hline Reference & {$[90]$} & {$[91]$} & {$[74]$} \\
\hline
\end{tabular}

that influenced the electrospinning process. They found that the relative humidity $(\mathrm{RH})$ can affect the diameter of the electrospun nanofibers. Lower $\mathrm{RH}$ values can cause a rapid evaporation of the solvent, resulting in thicker nanofiber. Higher RH values can cause slow evaporation of the solvent, resulting in thinner nanofibers.

Other than that, the formation of layer by layer electrospun mat composite fiber can assist the formation of nanofiber mats with a comparable proton conductivity and suppression in methanol permeability of the DMFC system. Previously, Liu et al. [56] conducted an experiment regarding the layer by layer composite electrospun fiber by incorporating sulfonated poly phenylene oxide and poly diallyl dimethyl ammonium chloride (sPPO/PDAC). In their study, they found that, at thickness of $\sim 25 \mu \mathrm{m}$, the electrospun fiber mats gave high methanol barrier properties in parallel with higher open circuit voltage of the DMFC system. In addition, the contribution of Nylon electrospun mats had indeed increased the mechanical strength of the layer by layer electrospun fiber sPPO/PDAC membrane.

Controllable hierarchical features such as nonwoven, aligned, or patterned fibres, nanoribbons, nanorods, random 3D structures, submicron spring, and twisted fibers with controlled diameter can also be prepared by modifying the solution and processing parameters and setup geometries [31]. Basically, the production of desirable nanofibers can be affected by many factors, including their application purpose primarily. For biomedical purpose, especially in tissue engineering scaffold, a few requirements had been drawn by Fang et al. [8] in their review in order to produce an electrospun fiber with a great performance. Table 5 lists some of the applications of the electrospun fiber and their desired properties, respectively. The application of electrospun nanofiber had been studied intensively by Huang et al. [2] in their paper. Different polymers with different characteristics were used in the electrospinning process. The polymers, however, have similar characteristics for respective applications.

\subsection{Collector Geometries of Electrospinning}

4.2.1. Collector Type. The formation of nanofibers can be classified into woven and nonwoven nanofibers. The type of collector used plays a big role in differentiating those types or nanofiber alignments. The methods utilized in developing aligned woven nanofibers consist of the use of oriented collector, as well as static double grounded collector [30,44].

(i) Oriented Collector. An oriented collector can be divided into two parts, which are rotating drum collector (Figure 5(a)) and rotating disk collector (Figure 5(b)). The rotating drum collector is used for collecting the aligned arrays nanofibers, whereas the rotating disk is used to collect uniaxially aligned nanofibers. The alignment fibers produced via rotating drum correspond to the rotational speed applied on the drum [44]. This type of electrospinning method is more complicated since the speed of the rotation needs to be well controlled to produce nanofibers with fine alignment.

The rotating disk collector can also be used for collecting continuous nanofibers, since nanofiber is highly attracted to the large electrical field applied at the edge of the disk [30]. According to Baji et al. [44], the use of this method can produce aligned nanofibers, even though only a small amount of fiber is produced due to the small area of the disk edge. In addition, Theron et al. [57] used the disk as a collector in producing polyethylene oxide (PEO) nanofibers. They found that the diameter of the electrospun nanofibers was $200 \mathrm{~nm}$ in average and the distance between the fibers varied from $1000 \mathrm{~nm}$ to $2000 \mathrm{~nm}$ due to the occurrence of repelling during reaching the collector. This eventually influenced the morphology of the formed nanofibers. The obtained morphology of the resultant fibers is as shown in Figures 5(a) and 5(b) [44].

(ii) Double Ground Collector. This setup is developed by introducing two parallel plates in the electrospinning system 


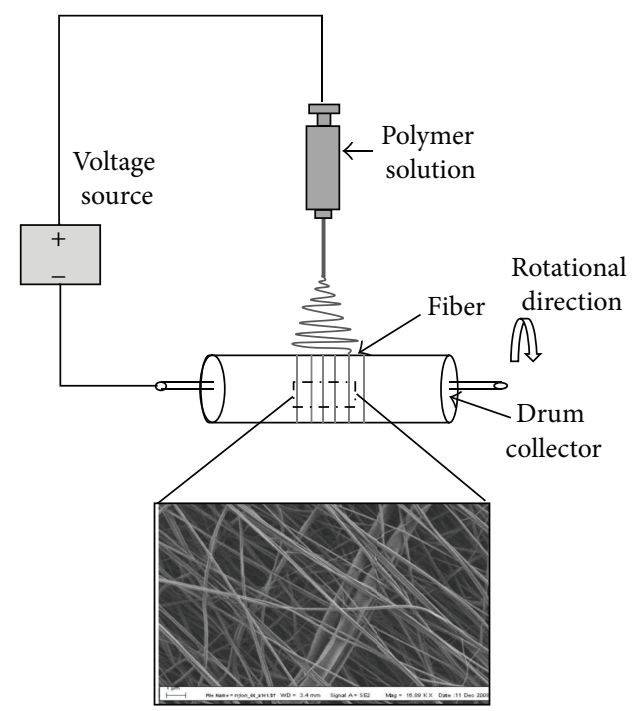

(a)

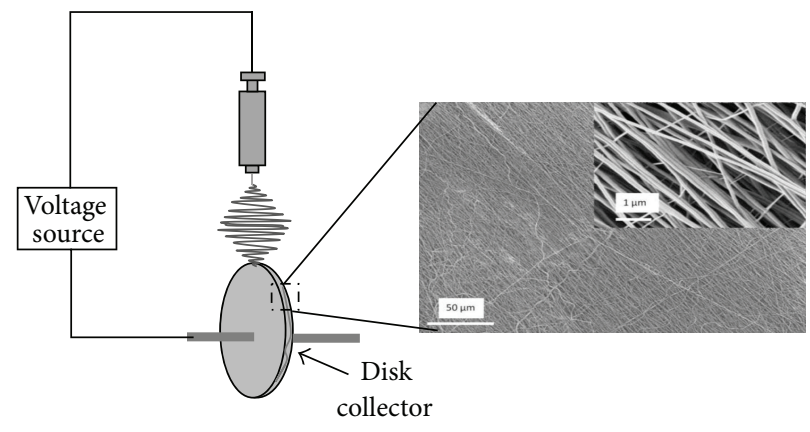

(b)

FIGURE 5: Oriented collector of electrospinning (a) rotating drum collector and (b) rotating disk collector [44]. Copyright ${ }^{\odot} 2014$ Elsevier B.V.

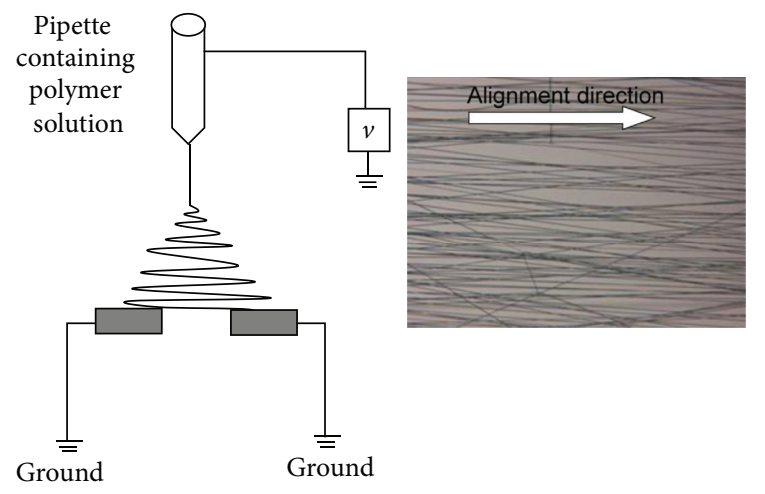

Figure 6: Double ground collector [44]. Copyright ${ }^{\odot} 2014$ Elsevier B.V.

as a collecting device for woven nanofibers. The fibers exiting the syringe tip tend to "straighten" themselves in the region between the two plates, where a formation of good alignment nanofibers can be obtained, as shown in Figure $6[30,44]$. Pan et al. [58] in their study on Nafion/poly (vinyl pyrrolidone) (PVP) nanowires (NPNWs) had used the collector, composed of two conductive substrates (silicon) separated by a void gap. They found that the transportation of proton to reach the cathode in NPNWs was easier and high proton conductivity in proportion with reduction in diameter was obtained due to the increase in degree of "texture" resulting from preferential orientation. They revealed that the proton conductivity could be enhanced by altering the diameter of the NPNWs to less than $2300 \mathrm{~nm}$.

Nevertheless, for a randomly oriented nanofiber (nonwoven) used as stationary collector, the collector can be divided into two types, which are vertical flat ground (Figure $7(\mathrm{a})$ ) and horizontal flat ground (Figure 7(b)) collectors. These types of setup consist of nonpreferable location for the nanofibers to deposited itself. However, these types of setup will make the nanofibers oriented by it and spread randomly on the collector.

The electric field/voltage supply will force the jet solution to twirl around before arriving at the top of the collector, in which, at this point, the gravitational force is negligible for the polymer solution. Rodoplu and Mutlu, [59] claimed that either in vertical or in horizontal direction of the needle, this configuration will still affect the formation of the Taylor cone and the droplet, since at this point the gravity still plays the role. They also claimed that, in vertical direction of the syringe instead of horizontal direction, this configuration will affect the shape of the droplet formation (Taylor cone formation) at the needle tip, which depends on the flat surface of the tip of needle. Kumar [60] conducted an experiment in order to study the effect of the collector type on the electrospun PVA. Four different types of collector were used, such as plane plate collector, drum rotator collector, grid collector, and edge collector. From the experiment, he found that the edge type collector showed a promising result on aligned fibers with good morphological characteristic and no bead was obtained compared with the other types of collector. Thus, this study proved that the collector types give a significant effect on fiber morphology of the electrospun fiber.

4.2.2. Collector Composition/Substrates. As the collector is in metal form, the composition or substrates on the collector for fiber collection can be in various forms such as glass, plastic, metal, or silicon wafer. However, the difference between these collector compositions will affect the structure of the electrospun fiber. For instance, Kim et al. [61] proved that the different types of composition used on the collector affected the structure of the poly (L-lactide) (PLLA) and poly 


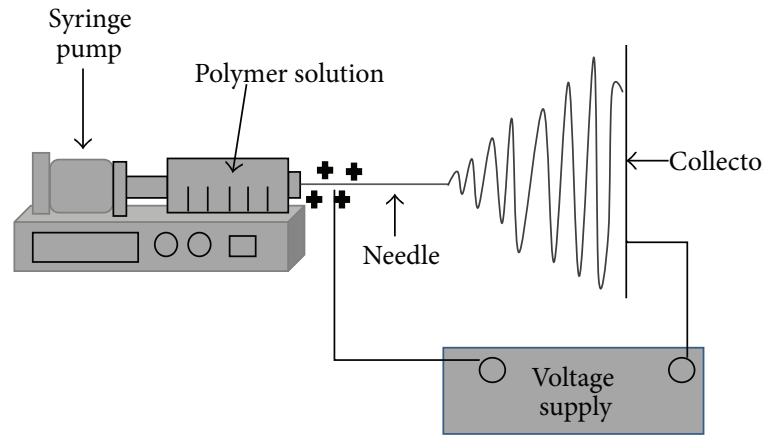

(a)

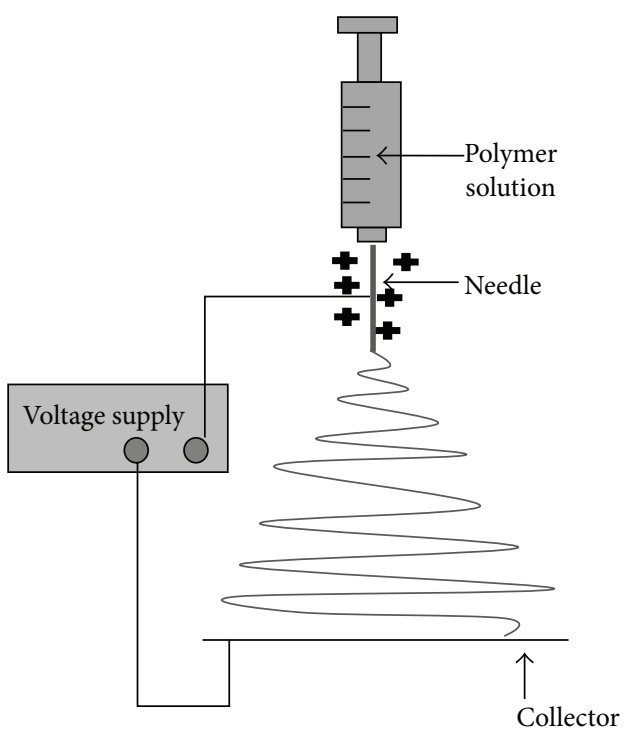

(b)

FIGURE 7: Stationary collector of electrospinning (a) horizontal flat ground collector and (b) vertical flat ground collector.

TABLE 6: Effects of collector composition on structure of electrospun fiber [61].

\begin{tabular}{lcc}
\hline Collector & PLLA & PLA50GA50 \\
\hline Metal & Smooth fiber & Smooth fiber \\
Water reservoir & - & $\begin{array}{c}\text { Shrinkage of nanofibers of } \\
\text { hydrophobic polymer }\end{array}$ \\
Methanol & Swelling & Large beads formed \\
\hline
\end{tabular}

(lactide-co-glycolide) (PLA50GA50) fibers. In the study, they dissolved the PLA50GA50 in dimethyl formamide (DMF) in order to form the $35 \mathrm{wt}$. \% of the polymer solution, and $6 \mathrm{wt}$. $\%$ of the PPLA solution was prepared by dissolving the PLLA in methylene chloride (MC) and DMF with solvent ratio of $65: 35$. Table 6 shows the structure of electrospun fiber at the collector composition.

Meanwhile, Liu and Hsieh [62] proved that the structure of electrospun cellulose acetate collected via different collector compositions such as copper mesh, aluminum foil, water, and paper will differ due to the influence of the conductivity of the collector itself. Conductive collector will help to dissipate the carried charge by the fibers, whereas the nonconductive collectors cannot help to dissipate the charge carried by the fiber. Eventually, this will result in more porous structure of fibers due to the repelling of fibers against one another. According to the Oxford Dictionary and Thesaurus, a conductive material is defined as the material which has the ability to conduct heat or electricity within itself. Tang et al. [63] used small nail as a collector in their study in order to produce a zigzag or helical structured nanofibers. They proposed that by reducing the area of the collector, the electric field can be concentrated at the nail, eventually producing helical nanofibers (Figure 8).

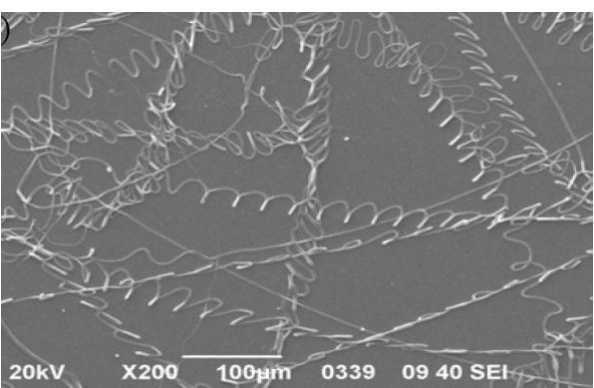

FIGURE 8: SEM image of the curled PVP microfiber electrospun at $40 \mathrm{kV}$ working voltage, at working distance of $10 \mathrm{~cm}[63]$. Copyright ${ }^{\odot}$ Chinese Physical Society.

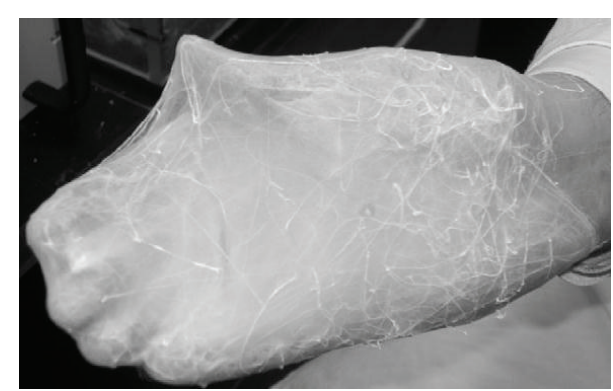

Figure 9: Nanofiber mat of EVOH on human hand [65]. Copyright ${ }^{\odot}$ Elsevier B.V.

In addition, Pham et al. [64] in their review had discussed poly (ethylene-co-vinyl alcohol), which was spun directly onto a human hand. They also studied the effect of the collector composition on the structure of the electrospun fiber. The spun fiber on human hand was also experimented by Kenawy et al. [65], in which after 30 minutes, they found 
TABLE 7: Standard collector dimension set by NaBond Technologies Co., Limited.

\begin{tabular}{lcl}
\hline Type of collector & Parameter & Specification \\
\hline \multirow{3}{*}{ Rotating drum } & Speed & $150-6000 \mathrm{rpm}$ \\
& Dimension & $\begin{array}{l}D=76 \mathrm{~mm}, 20 \mathrm{~mm}, 6 \mathrm{~mm} ; \\
L=235 \mathrm{~mm}\end{array}$ \\
& Disc collector & $\begin{array}{l}D=140 \mathrm{~mm} \text {, sharp edge or } \\
\text { flat edge }\end{array}$ \\
\hline \multirow{3}{*}{ Plate } & Size & A4, B5, A5 \\
& & $L=720 \mathrm{~mm}$, \\
& Dimension & $H=540 \mathrm{~mm}$, \\
& &
\end{tabular}

that a thick mat of EVOH was formed, coating a hand, as shown in Figure 9. This human hand is categorized as dielectric materials since it can support electrostatic field, even though this type of materials is a poor electric conductor [65]. The same interpretation goes to plastic petri dish. Thus, a wide range of the fiber formation, with regard to the structure of the fiber, can be obtained using different types of collector composition. Lin and Wang [66] conducted an experiment for producing PVA nanofiber having different thickness, $17 \mu \mathrm{m}, \sim 29 \mu \mathrm{m}$, and $\sim 41 \mu \mathrm{m}$, by using copper collection roll as a collector. In their study, the impregnated poly (vinyl alcohol) (PVA) nanofiber within the Nafion solution could indeed decrease the thickness of the pristine Nafion thin film up to $\sim 50 \mu \mathrm{m}$. Furthermore, the decrease in thickness of the nanocomposite membrane shows an increase in the proton conductivity due to the short pathway from anode to cathode without jeopardizing the methanol barrier properties for DMFC applications.

4.2.3. Dimension of the Collector. The dimension of the collector used in electrospinning process generally depends on the function of the nanofiber itself and the type of collector used. Beachley and Wen [67] performed a study on the effect of the size of two parallel plates on the electrospun fiber diameter and length. In the study, they used three different sizes of collector which were $(30.5 \times 7.5 \times 0.7) \mathrm{cm},(15 \times 4$ $\times 0.35) \mathrm{cm}$, and $(7.5 \times 2 \times 0.15) \mathrm{cm}$, and they found that, as the plate size increased, the fiber diameter also increased, as well as the fiber length. A standard dimension for the rotating drum collector and plate collector can be found from $\mathrm{NaBond}$ Technologies Co., Limited. The specification is tabulated in Table 7.

In reality, the collector dimension can be neglected since the formation of the desirable morphology and diameter of fibers rely more on the type of collector. This can be seen from a number of research works, which gave a great attention to the type of collector in order to obtain the desirable fibers. For instance, Buttafoco et al. [68] had used plate collector with ground aluminum foil with $6 \mathrm{~cm} \times 6 \mathrm{~cm}$ in dimension and rotating collector made of silicon tube with dimension of $3.1 \mathrm{~mm}$ outer diameter and $6 \mathrm{~cm}$ in length used in order to produce an electrospun collagen and elastin for tissue engineering applications. The nonwoven and partially oriented fibers were observed for plate and rotating collector, respectively.

4.3. Configurations of Nozzle in Electrospinning. In ejection and needle configuration, there are three main types of nozzle configuration such as single [69], side-by-side [70] and coaxial [59] (Table 8), which have become popular in producing different types of nanofibers, such as nanohollow fiber/core-shell fiber, and nanofiber.

\section{Application of Electrospun Nanofibers}

The unique properties of electrospun nanofibers have made it regain much attention in multiple applications. These unique properties are (1) extremely long length; (2) larger surface area to volume ratio; (3) complex pore size; and (4) alignment on the molecular level (either woven or nonwoven). These characteristics of electrospun nanofiber make it practical in various applications, as shown in Table 9.

\section{Potential of Electrospun Polymer/Inorganic Nanocomposite Membrane}

Even though Nafion exhibits excellent performance as proton exchange membrane, it is still difficult to be prepared as nanofiber structure. Electrospinning process is inapt for Nafion since it is not soluble in most common solvents. Furthermore, this insolubility often results in the formation of micelles, which causes the decrease in chain entanglement and incapability to electrospin fiber without any addition of high molecular weight carrier [21]. Rajesh [71], in his study, had successfully electrospun SPEEK nanofiber with $61 \%$ degree of sulfonation, in which he found that the conductivity of electrospun SPEEK membrane was higher compared to cast film SPEEK membrane. These performances were attributed to the increase in surface charge concentration and increase in water uptake, as well as the formation of ionconducting channels in the membrane matrix.

Chakrabarty et al. [72] prepared electrospun SPEEK (ESPEEK) for electrodialytic separation application, where they found that the ESPEEK was suitable for electrodialytic separation of $\mathrm{Na}^{+}$and $\mathrm{Ca}^{2+} / \mathrm{Mg}^{2+}$. This happened due to the formation of nanofibrous pore which restricted the migration of bivalent cation across the ESPEEK membrane. Lee et al. [73] produced dense membranes of $\mathrm{SiO}_{2} /$ SPEEK incorporated with Nafion solution for PEMFC application, where they found that the membranes showed excellent proton conductivity compared to the cast Nafion and SPEEK. Meanwhile, Choi et al. [74] studied electrospun nanofiber as a network ion-exchange membrane in fuel cell application. In their study, they found that the combination of sulfonated poly (arylene ether sulfone) (sPAES) electrospun fiber mats with Norland Optical Adhesive (NOA) 63 polymer solution gave an excellent proton conductivity compared to the pristine Nafion.

Figure 10 shows the schematic diagram of composite nanofiber network of an ion exchange membrane. This composite nanofiber network was built by four-step procedure 
TABLE 8: Configuration types of electrospinning.

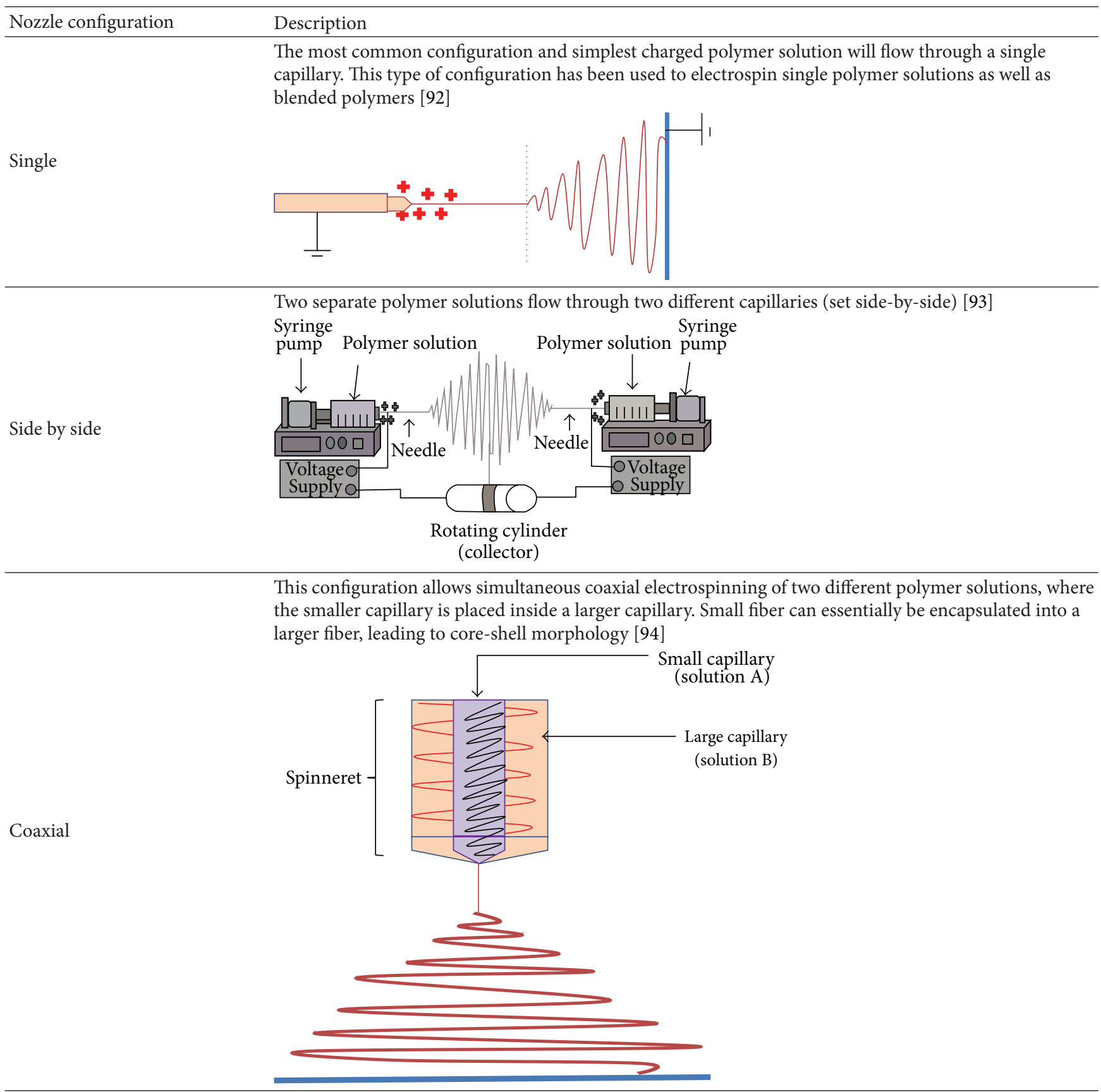

TABLE 9: Function of electrospun nanofibers in various fields of application [8, 30, 31, 38].

\begin{tabular}{ll}
\hline Sector & Function of electrospun nanofibers \\
\hline Biomedical & $\begin{array}{l}\text { Tissue engineering scaffolds; wound healing; neural prostheses; artificial heart valve; drug } \\
\text { delivery; release control }\end{array}$ \\
\hline Environmental protection & Filtration; metal ion adsorption and recovery \\
\hline Catalyst and enzyme carriers & Catalyst; enzymes \\
\hline Sensors & \\
\hline Energy harvest and storage & Solar cells; fuel cells; lithium ions batteries; super capacitors; hydrogen storage; photovoltaics \\
\hline Others & Gas turbine filter; engine filter; personal protective mask; gas separation \\
\hline
\end{tabular}




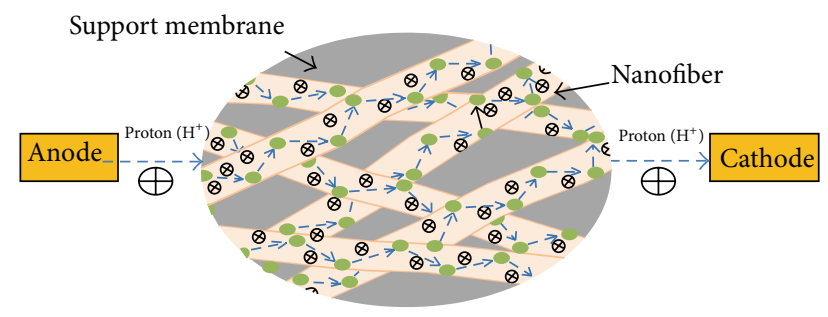

- Sulfonated cation exchange $\left(\mathrm{SO}_{3}{ }^{-}\right)$

$\oplus \mathrm{H}^{+}$atom

$\rightarrow$ Proton $\left(\mathrm{H}^{+}\right)$being transferred from anode to cathode via $\mathrm{SO}_{3}{ }^{-}$

FIGURE 10: Proton transport from anode to cathode within nanofiber network.

as explained by Choi et al. [74]. The figure clearly shows the transportation of proton from anode to cathode by the Grotthuss mechanism or proton hopping. The movement of proton involves a sequence of steps which contribute to the formation and breakage of hydrogen bonding. In Figure 10, the proton hops from one $\mathrm{SO}_{3}{ }^{-}$to another which leads to an effective proton conduction within composite nanofiber network. The presence of inert polymer as a support membrane to fill up the intervoid space between the nanofibers is crucial in order to ensure the stability and mechanical strength for composite nanofiber mat at different operation temperatures and pressure.

Montmorillonite (MMT) and hectorites are the most preferred clays for utilization in industrial applications due to their high cation exchange capacity, high surface area, high surface reactivity, and high barrier properties, compared to other types of clay [75]. Cloisite15A is a type of MMT, known as organoclay, since it is modified from MMT. It is very important as an additive in polymer nanocomposite due to its capability to enhance the compatibility with organic polymers [11]. Neppalli et al. [76] stated that the clay can exhibit a characteristic as a nucleating agent, as well as an obstacle to the polymer mobility. This, however, depends on the clay quantity and the dispersion state of the clay within the polymer matrix.

Impregnation of Cloisite15A into SPEEK membrane had been studied by Jaafar et al. [11]. Unfortunately, the dispersion of the Cloisite15A inside the polymer matrix was not completely exfoliated and the resulting dense membrane was barely enough for proton conductivity performance compared to the pristine Nafion 112 membrane. A solution towards performing good distribution and dispersion of Cloisite15A at nanometer size within the polymer matrix is still needed. Therefore, the introduction of electrospinning technique is believed to be able to help in producing electrospun Cloisite15A having smaller size and consequently avoiding agglomeration.

As has been concerned earlier, compared to the corresponding pure polymer membranes, many polymer-inorganic nanocomposite membranes showed much lower fuel permeability along with similar or improved proton conductivities due to the nanodispersion of layered silicates throughout polymer matrix. The combination of the flexibility and process ability from the base materials and selectivity and thermal stability of the inorganic fillers was significantly assisted by the good distribution of the inorganic materials. The introduction of fillers within the polymer matrix was found promising in increasing the tortuous effect and winding diffusion pathway for methanol to transfer through the nanocomposite membrane and eventually can reduce the methanol crossover. The complete exfoliation morphology of filler within polymer could further allow more cations to be mobile and available for conduction and simultaneously increase proton conductivity [10]. Based on the findings, it can be concluded that the morphological structure of a polymer-inorganic composite whether it is normal composite, intercalated, or exfoliated will significantly contribute to the performance of the PEM by means of proton conductivity and methanol permeability.

Other than that, the electrospinning process can favor the elongation of the chains and the ordering of the polymer. Wang et al. [77] had proven that the electrospinning process can favor the elongation of the chains and the ordering of the polymer instead of the function of the clay itself. Besides clay impregnation within SPEEK polymer matrix, Li et al. [78] had conducted an experiment regarding the incorporation of silver ion within the polymer matrix via electrospinning process. However, the use of silver ion within the SPEEK polymer was found to be not preferable for DMFC applications. Thus, it can be said that the contribution of electrospinning on many polymers and inorganic clay in processing an excellent membrane indeed gives a high performance of membrane not only in fuel cell, but also in many other applications as well.

\section{Proton Electrolyte Membrane Electrospun Nanofibers for Fuel Cell Application}

A desired proton electrolyte membrane for fuel cell application should comply with its intrinsic properties, especially on proton conductivity and fuel/gas crossover barrier properties. To adhere to these properties, the electrospinning parameters need to be controlled in order to produce excellent electrolyte electrospun nanofibers membrane. Basically, electrospinning parameters depend on the type of polymer used. However, an electrospun nanofiber membrane alone might face a low mechanical strength due to its small diameter and its potentials for defects to occur, which makes the electrospun nanofiber easily break [79]. Thus, a support material is needed in order to maintain the mechanical strength of the electrospun nanofibers, in parallel with the durability of the electrospun nanofibers membrane to withstand elevated temperature and pressure. Table 10 lists some of the previous researches on electrospinning parameters, which were involved in fabricating the electrospun nanofibers for fuel cell application.

Generally, the effects of electrospun fiber on proton conductivity and methanol permeability are mainly due to the formation of ionic alignment during electrospinning, 
TABLE 10: Summary of electrospinning parameters on electrospun nanofibers membrane in fuel cell application.

\begin{tabular}{|c|c|c|c|c|c|}
\hline Polymer & $\begin{array}{l}\text { Support } \\
\text { material }\end{array}$ & Type of fuel cell & Electrospinning parameters & Remark & Ref. \\
\hline $\begin{array}{l}\text { Polyvinyl alcohol, } \\
\text { PVA }\end{array}$ & Nafion & $\begin{array}{l}\text { Direct methanol } \\
\text { Fuel cell (DMFC) }\end{array}$ & $\begin{array}{l}\text { Distance from needle to collector: } \\
20 \mathrm{~cm} \\
\text { Solution flow rate: } 1.2 \mathrm{~mL} / \mathrm{h} \\
\text { Voltage potential: } 20 \mathrm{kV} \\
\text { I.D. needle: } 0.8 \mathrm{~mm} \\
\text { Collector: copper collection roll }\end{array}$ & $\begin{array}{l}\text { More straight and less tortuous effect on } \\
\text { Nafion/PVA nanofiber which leads to } \\
\text { increase in proton conductivity of the } \\
\text { membrane and reduction in membrane } \\
\text { crossover with a thickness of } \sim 50 \mu \mathrm{m}\end{array}$ & [66] \\
\hline $\begin{array}{l}\mathrm{SiO}_{2} / \text { sulfonated } \\
\text { poly (ether ether } \\
\text { ketone), SPEEK }\end{array}$ & Nafion & $\begin{array}{l}\text { Proton exchange } \\
\text { membrane fuel cell } \\
\text { (PEMFC) }\end{array}$ & $\begin{array}{l}\text { Distance from needle to collector: } \\
10 \mathrm{~cm} \\
\text { Voltage potential: } 15 \mathrm{kV} \\
\text { I.D. needle: } 0.15 \mathrm{~mm} \\
\text { Humidity: below } 15 \% \mathrm{RH}\end{array}$ & $\begin{array}{l}\text { Thickness of } \mathrm{SiO}_{2} / \mathrm{SPEEK} \text { nanofiber } \\
\text { membrane } 45 \mu \mathrm{m} \text { incorporation with } \\
\text { Nafion produces high proton } \\
\text { conductivity compared to cast Nafion } \\
\text { and SPEEK. The maximum power } \\
\text { density of } \mathrm{SiO}_{2} / \mathrm{SPEEK} \text { incorporation } \\
\text { with Nafion is } 170 \mathrm{~mW} / \mathrm{cm}^{3} \text { double than } \\
\text { cast Nafion }\end{array}$ & [73] \\
\hline $\begin{array}{l}\text { Polyvinyl alcohol, } \\
\text { PVA }\end{array}$ & Nafion & $\begin{array}{l}\text { Direct methanol } \\
\text { fuel cell (DMFC) }\end{array}$ & $\begin{array}{l}\text { Distance from needle to collector: } \\
25 \mathrm{~cm} \\
\text { Solution flow rate: } 0.5 \mathrm{ml} / \mathrm{h} \\
\text { Voltage potential: } 16 \mathrm{kV}\end{array}$ & $\begin{array}{l}\text { Succeeds in producing PVA nanofiber } \\
\text { having diameter of } 200-300 \mathrm{~nm} \\
\text { Contribution of Nafion as support } \\
\text { material has indeed increased the } \\
\text { mechanical and thermal properties of } \\
\text { the composite membrane with thickness } \\
\text { of composite membrane at } 46-47 \mu \mathrm{m} \\
\text { PVA nanofibers have indeed increased } \\
\text { the barrier properties on methanol } \\
\text { crossover }\end{array}$ & [95] \\
\hline $\begin{array}{l}\text { Sulfonated poly } \\
\text { (ether sulfone) } \\
\text { (SPES) }\end{array}$ & Nafion & $\begin{array}{l}\text { Direct methanol } \\
\text { fuel cell (DMFC) }\end{array}$ & $\begin{array}{l}\text { Distance from needle to collector: } \\
15 \mathrm{~cm} \\
\text { Voltage potential: } 19 \mathrm{kV} \\
\text { Collector: rotating cylindrical } \\
\text { stainless steel }\end{array}$ & $\begin{array}{l}\text { Proton conductivity of the bilayer } \\
\text { SPES/Nafion barely changes compared } \\
\text { to the Nafion } 117 / 112 \\
\text { The methanol crossover is reduced due } \\
\text { to the SPES nanofibers within Nafion } \\
\text { matrices }\end{array}$ & [96] \\
\hline
\end{tabular}

TABLE 11: Summary of the effect of electrospinning parameters on the performance of fuel cell in terms of proton conductivity and methanol permeability.

\begin{tabular}{|c|c|c|c|c|}
\hline Parameter increase & Fiber structure & $\begin{array}{c}\text { Proton } \\
\text { conductivity }\end{array}$ & $\begin{array}{c}\text { Methanol } \\
\text { permeability }\end{array}$ & Remark on methanol permeability \\
\hline Voltage applied & $\begin{array}{l}\text { Decrease in fiber } \\
\text { diameter, thinner fiber }\end{array}$ & Increases & Decreases & $\begin{array}{l}\text { With contribution of filler within the } \\
\text { parent polymer matrices }\end{array}$ \\
\hline $\begin{array}{l}\text { Needle to collector } \\
\text { distance }\end{array}$ & $\begin{array}{l}\text { Decrease in fiber } \\
\text { diameter }\end{array}$ & Increases & Decreases & $\begin{array}{l}\text { With contribution of filler within the } \\
\text { parent polymer matrices }\end{array}$ \\
\hline $\begin{array}{l}\text { Viscosity of dope } \\
\text { solution }\end{array}$ & $\begin{array}{l}\text { Fiber without beads, } \\
\text { smooth fiber }\end{array}$ & Increases & Decreases & $\begin{array}{l}\text { With contribution of filler within the } \\
\text { parent polymer matrices }\end{array}$ \\
\hline
\end{tabular}

as well as the formation of tortuous pathway for methanol to penetrate into the membrane matrices. Furthermore, the contribution of filler within the polymer matrix will improve the barrier properties for methanol crossover. As a conclusion, a small diameter of electrospun fiber with an excellent proton conductivity and higher resistance on fuel/gas permeability can be obtained through the optimization of different parameters of the electrospinning equipment. Table 11 presents some of the effects of electrospinning parameters, such as needle to collector distance, viscosity of the solution, solution flow rate and voltage applied on the fiber morphology, proton conductivity, and methanol permeability.

\section{Conclusion and Outlook}

The development of electrospun polymer electrolyte membrane for direct methanol fuel cell (DMFC) has gained a lot of attention from researchers due to its capability in sustaining proton conductivity, as well as capability to suppress methanol permeability without jeopardizing the fuel cell system. A significant amount of work has been done for 
preparing electrospun sulfonated poly (ether ether ketone) (SPEEK) for fuel cell application, as well as optimizing the degree of sulfonation for spinnable SPEEK solution. However, several existing challenges in electrospinning process still need to be overcome prior to formation of smooth electrospun fiber, such as solution parameters, controlled parameters, and ambient parameters. Despite all the challenges, the electrospinning method for preparing an electrospun SPEEK/Cloisite15A is undeniably potential in enhancing methanol permeability barrier properties, as well as proton conductivity for DMFC.

\section{Conflict of Interests}

The authors declare that there is no conflict of interests regarding the publication of this paper.

\section{Acknowledgments}

The author Hazlina Junoh would like to express gratitude to the Ministry of Science, Technology and Innovation (MOSTI), Malaysia, for the grant with vote number of R.J130000.7842.4S057 for the financial support and also to the Research Management Centre (RMC), UTM, for supporting related research management activities.

\section{References}

[1] A. Martins, J. V. Araújo, R. L. Reis, and N. M. Neves, "Electrospun nanostructured scaffolds for tissue engineering applications," Nanomedicine, vol. 2, no. 6, pp. 929-942, 2007.

[2] Z.-M. Huang, Y.-Z. Zhang, M. Kotaki, and S. Ramakrishna, "A review on polymer nanofibers by electrospinning and their applications in nanocomposites," Composites Science and Technology, vol. 63, no. 15, pp. 2223-2253, 2003.

[3] R. Dersch, M. Steinhart, U. Boudriot, A. Greiner, and J. H. Wendorff, "Nanoprocessing of polymers: applications in medicine, sensors, catalysis, photonics," Polymers for Advanced Technologies, vol. 16, no. 2-3, pp. 276-282, 2005.

[4] H. T. Chiu, J. M. Lin, T. H. Cheng, and S. Y. Chou, "Fabrication of electrospun polyacrylonitrile ion-exchange membranes for application in lysozym," Express Polymer Letters, vol. 5, no. 4, pp. 308-317, 2011.

[5] S. Kaur, D. Rana, T. Matsuura, S. Sundarrajan, and S. Ramakrishna, "Preparation and characterization of surface modified electrospun membranes for higher filtration flux," Journal of Membrane Science, vol. 390-391, pp. 235-242, 2012.

[6] Z.-G. Wang, L.-S. Wan, Z.-M. Liu, X.-J. Huang, and Z.-K. Xu, "Enzyme immobilization on electrospun polymer nanofibers: an overview," Journal of Molecular Catalysis B: Enzymatic, vol. 56, no. 4, pp. 189-195, 2009.

[7] H. Jia, G. Zhu, B. Vugrinovich, W. Kataphinan, D. H. Reneker, and P. Wang, "Enzyme-carrying polymeric nanofibers prepared via electrospinning for use as unique biocatalysts," Biotechnology Progress, vol. 18, no. 5, pp. 1027-1032, 2002.

[8] J. Fang, X. Wang, and T. Lin, "Functional applications of electrospun nanofibers," in Nanofibers-Production, Properties and Functional Applications, pp. 287-326, InTech, 2011.

[9] Y. I. Tien and K. H. Wei, "Hydrogen bonding and mechanical properties in segmented montmorillonite/polyurethane nanocomposites of different hard segment ratios," Polymer, vol. 42, no. 7, pp. 3213-3221, 2001.

[10] M. Wang and S. Dong, "Enhanced electrochemical properties of nanocomposite polymer electrolyte based on copolymer with exfoliated clays," Journal of Power Sources, vol. 170, no. 2, pp. 425-432, 2007.

[11] J. Jaafar, A. F. Ismail, and T. Matsuura, "Preparation and barrier properties of SPEEK/Cloisite 15A/TAP nanocomposite membrane for DMFC application," Journal of Membrane Science, vol. 345, no. 1-2, pp. 119-127, 2009.

[12] F. Croce, G. B. Appetecchi, L. Persi, and B. Scrosati, "Nanocomposite polymer electrolytes for lithium batteries," Nature, vol. 394, no. 6692, pp. 456-458, 1998.

[13] D. Golodnitsky, G. Ardel, and E. Peled, "Ion-transport phenomena in concentrated PEO-based composite polymer electrolytes," Solid State Ionics, vol. 147, no. 1-2, pp. 141-155, 2002.

[14] A. Kumar and M. Deka, Advances in Nanocomposites-Synthesis, Characterization and Industrial Applications, InTech, Vienna, Austria, 2010.

[15] M. M. Hasani-Sadrabadi, E. Dashtimoghadam, K. Sarikhani, F. S. Majedi, and G. Khanbabaei, "Electrochemical investigation of sulfonated poly (ether ether ketone)/clay nanocomposite membranes for moderate temperature fuel cell applications," Journal of Power Sources, vol. 195, pp. 2450-2456, 2010.

[16] S. Bian, A Study of the Material Properties of Silicone Nanocomposites Developed by Electrospinning, University of Waterloo, Waterloo, Canada, 2013.

[17] S. Mekhilef, R. Saidur, and A. Safari, "Comparative study of different fuel cell technologies," Renewable and Sustainable Energy Reviews, vol. 16, no. 1, pp. 981-989, 2012.

[18] L. Zhang, S.-R. Chae, Z. Hendren, J.-S. Park, and M. R. Wiesner, "Recent advances in proton exchange membranes for fuel cell applications," Chemical Engineering Journal, vol. 204-205, pp. 87-97, 2012.

[19] G. G. Kumar and K. S. Nahm, "Polymer nanocompositesfuel cell applications," in Advances in Nanocomposite-Synthesis, Characterization and Industrial Applications, pp. 639-660, InTech Europe, Vienna, Austria, 2011.

[20] S. M. J. Zaidi, "Preparation and characterization of composite membranes using blends of SPEEK/PBI with boron phosphate," Electrochimica Acta, vol. 50, no. 24, pp. 4771-4777, 2005.

[21] M. W. Cason, "Electrospun nafion nanofibers for proton exchange membranes," Literature Seminar, 2010.

[22] S. S. Mohtar, A. F. Ismail, and T. Matsuura, "Preparation and characterization of SPEEK/MMT-STA composite membrane for DMFC application," Journal of Membrane Science, vol. 371, no. 1-2, pp. 10-19, 2011.

[23] L. Li, J. Zhang, and Y. Wang, "Sulfonated poly(ether ether ketone) membranes for direct methanol fuel cell," Journal of Membrane Science, vol. 226, no. 1-2, pp. 159-167, 2003.

[24] J.-M. Thomassin, C. Pagnoulle, G. Caldarella, A. Germain, and R. Jérôme, "Contribution of nanoclays to the barrier properties of a model proton exchange membrane for fuel cell application," Journal of Membrane Science, vol. 270, no. 1-2, pp. 50-56, 2006.

[25] D. W. Litchfield and D. G. Baird, "The rheology of high aspect ratio nano-particle filled liquids," Rheology Reviews, pp. 1-60, 2006.

[26] A. H. M. Yusof, M. A. M. Amin, A. F. Ismail, M. N. Anam, and N. A. N. Mahmud, "Fabrication and effect of sulfonated poly (ether ether ketone) with Cloisite15A nanoclays for microbial fuel cell application," International Journal of Sustainable Construction Engineering \& Technology, vol. 4, no. 1, pp. 63-74, 2013. 
[27] R. Jiang, H. R. Kunz, and J. M. Fenton, "Investigation of membrane property and fuel cell behavior with sulfonated poly(ether ether ketone) electrolyte: temperature and relative humidity effects," Journal of Power Sources, vol. 150, no. 1-2, pp. 120-128, 2005.

[28] Y.-H. Su, Y.-L. Liu, Y.-M. Sun et al., "Proton exchange membranes modified with sulfonated silica nanoparticles for direct methanol fuel cells," Journal of Membrane Science, vol. 296, no. 1-2, pp. 21-28, 2007.

[29] R. Gosalawit, S. Chirachanchai, S. Shishatskiy, and S. P. Nunes, "Sulfonated montmorillonite/sulfonated poly(ether ether ketone) (SMMT/SPEEK) nanocomposite membrane for direct methanol fuel cells (DMFCs)," Journal of Membrane Science, vol. 323, no. 2, pp. 337-346, 2008.

[30] B. P. Sautther, Continuous Polymer Nanofibers Using Electrospinning, NSF-REU Summer Program, Chicago, Ill, USA, 2005.

[31] S. Cavaliere, S. Subianto, I. Savych, D. J. Jones, and J. Rozière, "Electrospinning: designed architectures for energy conversion and storage devices," Energy and Environmental Science, vol. 4, no. 12, pp. 4761-4785, 2011.

[32] C. Feng, K. C. Khulbe, and T. Matsuura, "Recent progress in the preparation, characterization, and applications of nanofibers and nanofiber membranes via electrospinning/interfacial polymerization," Journal of Applied Polymer Science, vol. 115, no. 2, pp. 756-776, 2010.

[33] P. Lu and B. Ding, "Applications of electrospun fibers," Recent Patents on Nanotechnology, vol. 2, no. 3, pp. 169-182, 2008.

[34] I. S. Chronakis, "Novel nanocomposites and nanoceramics based on polymer nanofibers using electrospinning process-a review," Journal of Materials Processing Technology, vol. 167, no. 2-3, pp. 283-293, 2005.

[35] A. Frenot and I. S. Chronakis, "Polymer nanofibers assembled by electrospinning," Current Opinion in Colloid and Interface Science, vol. 8, no. 1-2, pp. 64-75, 2003.

[36] X. Xiong, Q. Li, X.-C. Zhang, L. Wang, Z.-X. Guo, and J. Yu, "Poly(vinylidene fluoride)/silica nanocomposite membranes by electrospinning," Journal of Applied Polymer Science, vol. 129, no. 3, pp. 1089-1095, 2013.

[37] D. Zhang, A. B. Karki, D. Rutman et al., "Electrospun polyacrylonitrile nanocomposite fibers reinforced with $\mathrm{Fe}_{3} \mathrm{O}_{4}$ nanoparticles: fabrication and property analysis," Polymer, vol. 50, no. 17, pp. 4189-4198, 2009.

[38] V. Thavasi, G. Singh, and S. Ramakrishna, "Electrospun nanofibers in energy and environmental applications," Energy and Environmental Science, vol. 1, no. 2, pp. 205-221, 2008.

[39] A. Zucchelli, D. Fabiani, C. Gualandi, and M. L. Focarete, "An innovative and versatile approach to design highly porous, patterned, nanofibrous polymeric materials," Journal of Materials Science, vol. 44, no. 18, pp. 4969-4975, 2009.

[40] J. Bajáková, J. Chaloupek, D. Lukáš, and M. Lacarin, “Drawingthe production of individual nanofibers by experimental method," in Proceedings of the 3rd International Conference on Nanotechnology-Smart Materials (NANOCON '11), Bern, Switzerland, 2011.

[41] C. R. Martin, "Membrane-based synthesis of nanomaterials," Chemistry of Materials, vol. 8, no. 8, pp. 1739-1746, 1996.

[42] A. Greiner and J. H. Wendorff, "Electrospinning: a fascinating method for the preparation of ultrathin fibers," Angewandte Chemie International Edition, vol. 46, no. 30, pp. 5670-5703, 2007.

[43] Y. Liu, J.-H. He, J.-Y. Yu, and H.-M. Zeng, "Controlling numbers and sizes of beads in electrospun nanofibers," Polymer International, vol. 57, no. 4, pp. 632-636, 2008.
[44] A. Baji, Y.-W. Mai, S.-C. Wong, M. Abtahi, and P. Chen, "Electrospinning of polymer nanofibers: effects on oriented morphology, structures and tensile properties," Composites Science and Technology, vol. 70, no. 5, pp. 703-718, 2010.

[45] M. Bognitzki, W. Czado, T. Frese et al., "Nanostructured fibers via electrospinning," Advanced Materials, vol. 13, pp. 70-72, 2001.

[46] P. Uttayarat, A. Perets, M. Li et al., "Micropatterning of threedimensional electrospun polyurethane vascular grafts," Acta Biomaterialia, vol. 6, no. 11, pp. 4229-4237, 2010.

[47] D. Li and Y. Xia, "Electrospinning of nanofibers: reinventing the wheel?” Advanced Materials, vol. 16, no. 14, pp. 1151-1170, 2004.

[48] M. AbdElmoula, Optical, Electrical and Catalytic Properties of Titania Nanotubes, Northeastern University, Boston, Mass, USA, 2011.

[49] M. Maleki, M. Latifi, and M. Amani-Tehran, "Optimizing electrospinning parameters for finest diameter of nano fibers," World Academy of Science, Engineering and Technology, vol. 64, pp. 389-392, 2010.

[50] Z. Li and C. Wang, One Dimensional Nanostructures Electrospinning Technique and Unique Nanofibers, Springer, New York, NY, USA, 2013.

[51] C. J. Thompson, G. G. Chase, A. L. Yarin, and D. H. Reneker, "Effects of parameters on nanofiber diameter determined from electrospinning model," Polymer, vol. 48, no. 23, pp. 6913-6922, 2007.

[52] T. Subbiah, G. S. Bhat, R. W. Tock, S. Parameswaran, and S. S. Ramkumar, "Electrospinning of nanofibers," Journal of Applied Polymer Science, vol. 96, no. 2, pp. 557-569, 2005.

[53] A. Formhals, "Method and apparatus for spinning," United States Patent Office, 2,160,962, 1939.

[54] J. Pelipenko, J. Kristl, B. Janković, S. Baumgartner, and P. Kocbek, "The impact of relative humidity during electrospinning on the morphology and mechanical properties of nanofibers," International Journal of Pharmaceutics, vol. 456, no. 1, pp. 125-134, 2013.

[55] S. W. Choi, Y.-Z. Fu, Y. R. Ahn, S. M. Jo, and A. Manthiram, "Nafion-impregnated electrospun polyvinylidene fluoride composite membranes for direct methanol fuel cells," Journal of Power Sources, vol. 180, no. 1, pp. 167-171, 2008.

[56] D. S. Liu, M. M. Mannarino, G. C. Rutledge, and P. T. Hammond, "Mechanical and transport properties of layer-bylayer electrospun composite proton exchange membranes for fuel cell applications," ACS Applied Materials \& Interfaces, vol. 5, pp. 8155-8164, 2013.

[57] A. Theron, E. Zussman, and A. L. Yarin, "Electrostatic fieldassisted alignment of electrospun nanofibres," Nanotechnology, vol. 12, no. 3, pp. 384-390, 2001.

[58] C. Pan, H. Wu, C. Wang et al., "Nanowire-based highperformance "Micro Fuel Cells": one-nanowire, one fuel cell," Advanced Materials, vol. 20, no. 9, pp. 1644-1648, 2008.

[59] D. Rodoplu and M. Mutlu, "Effects of electrospinning setup and process parameters on nanofiber morphology intended for the modification of quartz crystal microbalance surfaces," Journal of Engineered Fibers and Fabrics, vol. 7, no. 2, pp. 118-123, 2012.

[60] P. Kumar, Effect of Collector on Electrospinning to Fabricate Aligned Nanofiber, National Institute of Technology, Rourkela, India, 2012.

[61] H. S. Kim, K. Kim, H. J. Jin, and I.-J. Chin, "Morphological characterization of electrospun nano-fibrous membranes of biodegradable poly(L-lactide) and poly(lactide-co-glycolide)," Macromolecular Symposia, vol. 224, pp. 145-154, 2005. 
[62] H. Liu and Y.-L. Hsieh, "Ultrafine fibrous cellulose membranes from electrospinning of cellulose acetate," Journal of Polymer Science B: Polymer Physics, vol. 40, no. 18, pp. 2119-2129, 2002.

[63] C.-C. Tang, J.-C. Chen, Y.-Z. Long, H.-X. Yin, B. Sun, and H.D. Zhang, "Preparation of curled microfibers by electrospinning with tip collector," Chinese Physics Letters, vol. 28, no. 5, Article ID 056801, 2011.

[64] Q. P. Pham, U. Sharma, and A. G. Mikos, "Electrospinning of polymeric nanofibers for tissue engineering applications: a review," Tissue Engineering, vol. 12, no. 5, pp. 1197-1211, 2006.

[65] E.-R. Kenawy, J. M. Layman, J. R. Watkins et al., "Electrospinning of poly(ethylene-co-vinyl alcohol) fibers," Biomaterials, vol. 24, no. 6, pp. 907-913, 2003.

[66] H.-L. Lin and S.-H. Wang, "Nafion/poly(vinyl alcohol) nanofiber composite and Nafion/poly(vinyl alcohol) blend membranes for direct methanol fuel cells," Journal of Membrane Science, vol. 452, pp. 253-262, 2014.

[67] V. Beachley and X. Wen, "Effect of electrospinning parameters on the nanofiber diameter and length," Materials Science and Engineering C, vol. 29, no. 3, pp. 663-668, 2009.

[68] L. Buttafoco, N. G. Kolkman, P. Engbers-Buijtenhuijs et al., "Electrospinning of collagen and elastin for tissue engineering applications," Biomaterials, vol. 27, no. 5, pp. 724-734, 2006.

[69] N. Zhu and X. Chen, Advances in Biomaterials Science and Biomedical Applications, InTech, Hampshire, UK, 2013.

[70] F. Li, Y. Zhao, and Y. Song, Nano Channel and Capsule by Coaxial Electrospinning, Nanofiber, InTech, 2010.

[71] K. P. Rajesh, Studies on Ion Conducting Properties of Electrospin Polymer Fibers, Indian Institute of Technology Madras, Chennai, India, 2011.

[72] T. Chakrabarty, M. Kumar, K. P. Rajesh, V. K. Shahi, and T. S. Natarajan, "Nano-fibrous sulfonated poly(ether ether ketone) membrane for selective electro-transport of ions," Separation and Purification Technology, vol. 75, no. 2, pp. 174-182, 2010.

[73] C. Lee, S. M. Jo, J. Choi et al., " $\mathrm{SiO}_{2}$ /sulfonated poly ether ether ketone (SPEEK) composite nanofiber mat supported proton exchange membranes for fuel cells," Journal of Materials Science, vol. 48, no. 10, pp. 3665-3671, 2013.

[74] J. Choi, K. M. Lee, R. Wycisk, P. N. Pintauro, and P. T. Mather, "Nanofiber network ion-exchange membranes," Macromolecules, vol. 41, no. 13, pp. 4569-4572, 2008.

[75] J. Jaafar, A. F. Ismail, T. Matsuura, and K. Nagai, "Performance of SPEEK based polymer-nanoclay inorganic membrane for DMFC," Journal of Membrane Science, vol. 382, no. 1-2, pp. 202211, 2011.

[76] R. Neppalli, S. Wanjale, M. Birajdar, and V. Causin, "The effect of clay and of electrospinning on the polymorphism, structure and morphology of poly(vinylidene fluoride)," European Polymer Journal, vol. 49, no. 1, pp. 90-99, 2013.

[77] Y. Wang, M. Li, J. Rong et al., "Enhanced orientation of PEO polymer chains induced by nanoclays in electrospun $\mathrm{PEO} /$ clay composite nanofibers," Colloid and Polymer Science, vol. 291, no. 6, pp. 1541-1546, 2013.

[78] X. Li, X. Hao, and H. Na, "Preparation of nanosilver particles into sulfonated poly(ether ether ketone) (S-PEEK) nanostructures by electrospinning," Materials Letters, vol. 61, no. 2, pp. 421-426, 2007.

[79] S. Zhnag, Mechanical and Physical Properties of Electrospun Nanofibers, North Carolina State University, 2009.

[80] L. Du, X. Yan, G. He, X. Wu, Z. Hu, and Y. Wang, "SPEEK proton exchange membranes modified with silica sulfuric acid nanoparticles," International Journal of Hydrogen Energy, vol. 37, no. 16, pp. 11853-11861, 2012.

[81] S. M. J. Zaidi, S. D. Mikhailenko, G. P. Robertson, M. D. Guiver, and S. Kaliaguine, "Proton conducting composite membranes from polyether ether ketone and heteropolyacids for fuel cell applications," Journal of Membrane Science, vol. 173, no. 1, pp. 17-34, 2000.

[82] M.-K. Song, S.-B. Park, Y.-T. Kim, and H.-W. Rhee, "Nanocomposite polymer membrane based on cation exchange polymer and nano-dispersed clay sheets," Molecular Crystals and Liquid Crystals, vol. 407, no. 15-23, pp. 411-419, 2003.

[83] M.-K. Song, S.-B. Park, Y.-T. Kim, K.-H. Kim, S.-K. Min, and H.-W. Rhee, "Characterization of polymer-layered silicate nanocomposite membranes for direct methanol fuel cells," Electrochimica Acta, vol. 50, no. 2-3, pp. 639-643, 2004.

[84] P. Bébin, M. Caravanier, and H. Galiano, "Nafion/clay- $\mathrm{SO}_{3} \mathrm{H}$ membrane for proton exchange membrane fuel cell application," Journal of Membrane Science, vol. 278, no. 1-2, pp. 35-42, 2006.

[85] J. Doshi and D. H. Reneker, "Electrospinning process and applications of electrospun fibers," Journal of Electrostatics, vol. 35, no. 2-3, pp. 151-160, 1995.

[86] J. M. Deitzel, J. Kleinmeyer, D. Harris, and N. C. Beck Tan, “The effect of processing variables on the morphology of electrospun nanofibers and textiles," Polymer, vol. 42, no. 1, pp. 261-272, 2001.

[87] R. Jalili, S. A. Hosseini, and M. Morshed, "The effects of operating parameters on the morphology of electrospun polyacrilonitrile nanofibres," Iranian Polymer Journal, vol. 14, no. 12, pp. 1074-1081, 2005.

[88] S.-H. Tan, R. Inai, M. Kotaki, and S. Ramakrishna, "Systematic parameter study for ultra-fine fiber fabrication via electrospinning process," Polymer, vol. 46, no. 16, pp. 6128-6134, 2005.

[89] H. Fong, I. Chun, and D. H. Reneker, "Beaded nanofibers formed during electrospinning," Polymer, vol. 40, no. 16, pp. 4585-4592, 1999.

[90] W.-J. Li, C. T. Laurencin, E. J. Caterson, R. S. Tuan, and F. K. Ko, "Electrospun nanofibrous structure: a novel scaffold for tissue engineering," Journal of Biomedical Materials Research, vol. 60, no. 4, pp. 613-621, 2002.

[91] K. M. Yun, C. J. Hogan Jr., Y. Matsubayashi, M. Kawabe, F. Iskandar, and K. Okuyama, "Nanoparticle filtration by electrospun polymer fibers," Chemical Engineering Science, vol. 62, no. 17, pp. 4751-4759, 2007.

[92] F. Abdel-Hady, A. Alzahrany, and M. Hamed, "Experimental validation of upward electrospinning process," ISRN Nanotechnology, vol. 2011, Article ID 851317, 14 pages, 2011.

[93] F. Xu, L. Li, and X. Cui, "Fabrication of aligned side-by-side $\mathrm{TiO}_{2} / \mathrm{SnO}_{2}$ nanofibers via dual-opposite-spinneret electrospinning," Journal of Nanomaterials, vol. 2012, Article ID 575926, 5 pages, 2012.

[94] T. J. Sill and H. A. von Recum, "Electrospinning: applications in drug delivery and tissue engineering," Biomaterials, vol. 29, no. 13, pp. 1989-2006, 2008.

[95] S. Mollá and V. Compañ, "Polyvinyl alcohol nanofiber reinforced Nafion membranes for fuel cell applications," Journal of Membrane Science, vol. 372, no. 1-2, pp. 191-200, 2011.

[96] I. Shabani, M. M. Hasani-Sadrabadi, V. Haddadi-Asl, and M. Soleimani, "Nanofiber-based polyelectrolytes as novel membranes for fuel cell applications," Journal of Membrane Science, vol. 368, no. 1-2, pp. 233-240, 2011. 

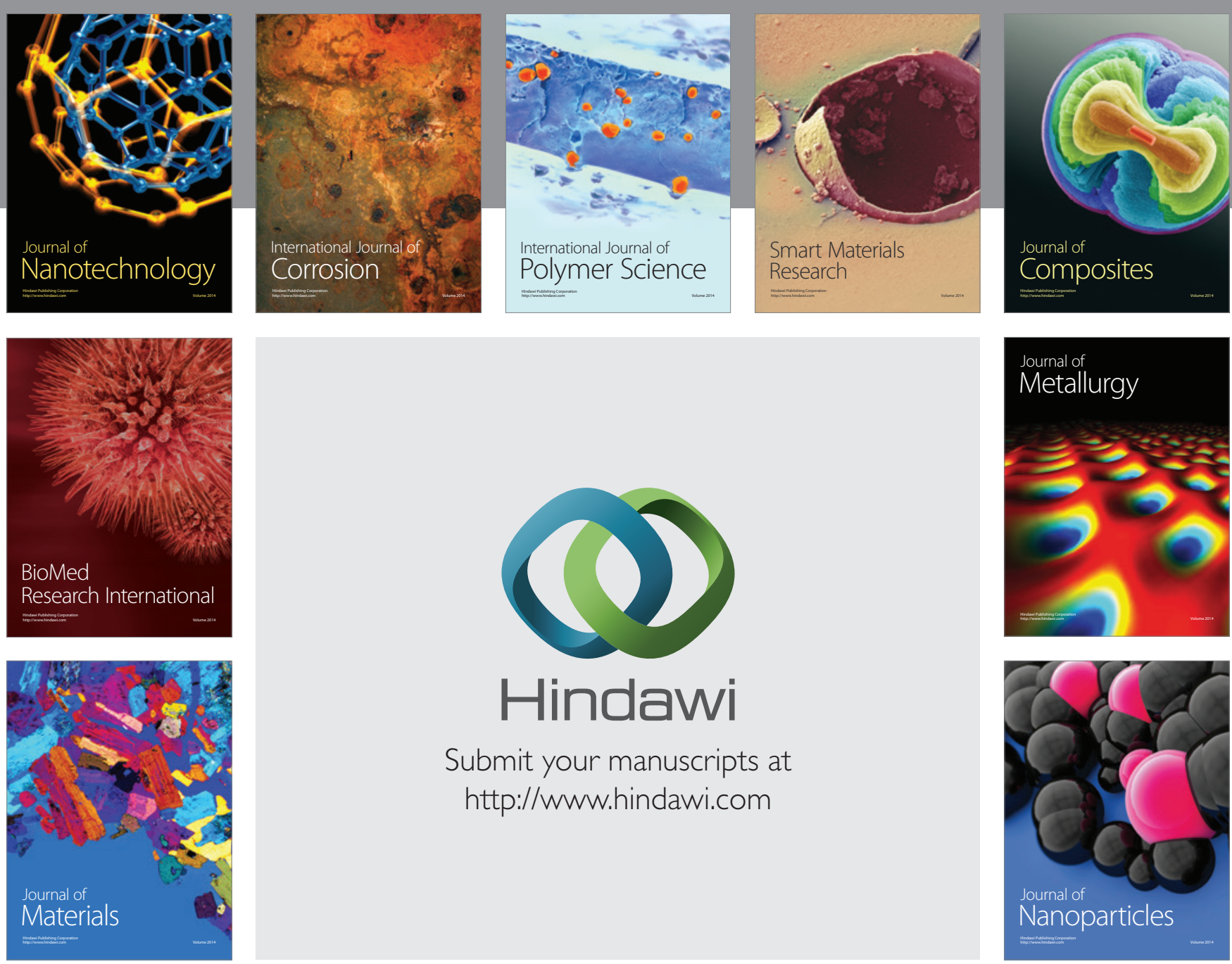

Submit your manuscripts at http://www.hindawi.com
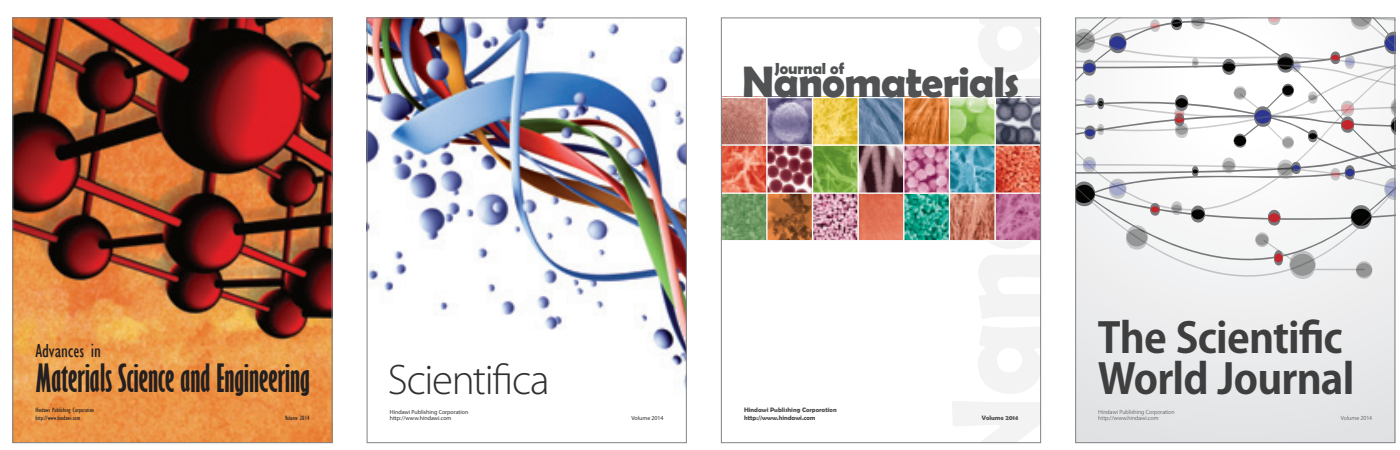

\section{The Scientific World Journal}
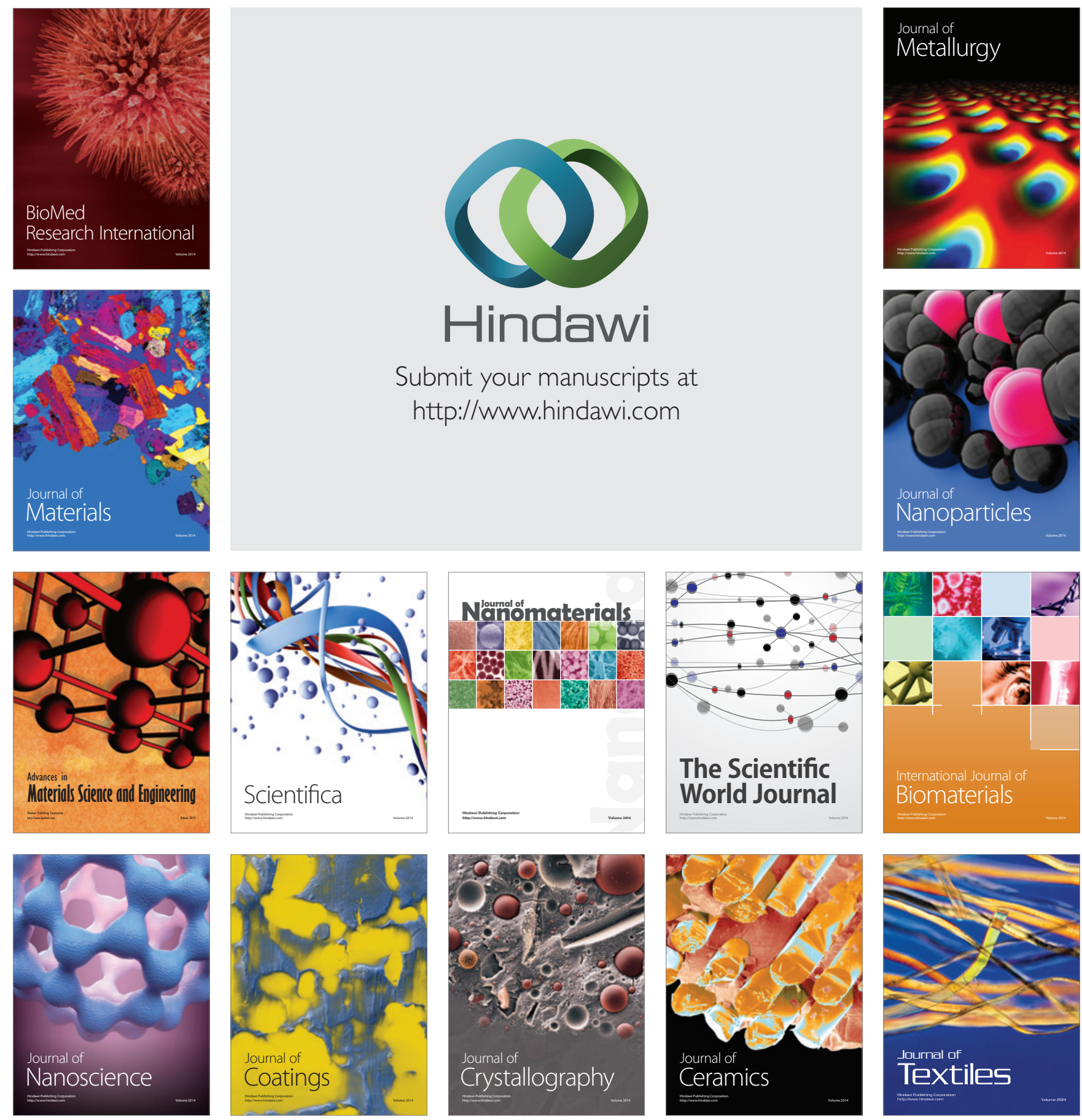